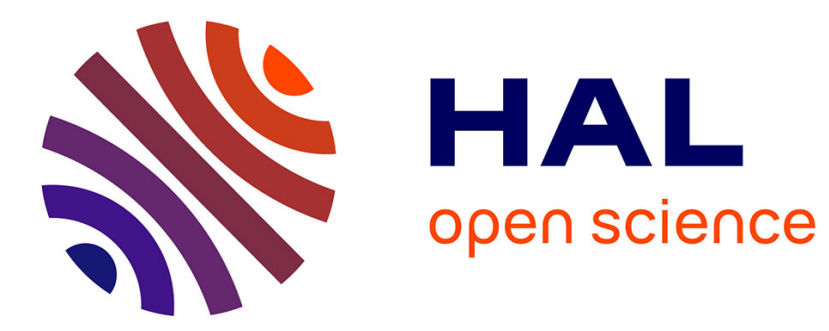

\title{
Retailers expansion mode choice in foreign markets: Antecedents for expansion mode choice in the light of internationalization theories
}

\author{
Karine Picot-Coupey, Steve L. Burt, Gérard Cliquet
}

\section{- To cite this version:}

Karine Picot-Coupey, Steve L. Burt, Gérard Cliquet. Retailers expansion mode choice in foreign markets: Antecedents for expansion mode choice in the light of internationalization theories. Journal of Retailing and Consumer Services, 2014, 21 (6), pp.976-991. 10.1016/j.jretconser.2014.08.018 . halshs-01075645

\author{
HAL Id: halshs-01075645 \\ https://shs.hal.science/halshs-01075645
}

Submitted on 9 Dec 2014

HAL is a multi-disciplinary open access archive for the deposit and dissemination of scientific research documents, whether they are published or not. The documents may come from teaching and research institutions in France or abroad, or from public or private research centers.
L'archive ouverte pluridisciplinaire HAL, est destinée au dépôt et à la diffusion de documents scientifiques de niveau recherche, publiés ou non, émanant des établissements d'enseignement et de recherche français ou étrangers, des laboratoires publics ou privés. 


\title{
Retailers' Expansion Mode Choice in Foreign MARKets: Antecedents For Expansion Mode Choice IN THE Light OF InTERnationalization THEORIES
}

\author{
Karine Picot-Coupey ${ }^{\mathrm{a}}{ }^{*}$, Steve L. Burt ${ }^{\mathrm{b}}$ and Gérard Cliquet ${ }^{\mathrm{a}}$ \\ ${ }^{\mathrm{a}}$ Centre for Research in Economics and Management, University of Rennes 1, IGR-IAE, \\ Rennes, France \\ ${ }^{\mathbf{b}}$ Institute for Retail Studies, University of Stirling, Scotland, UK
}

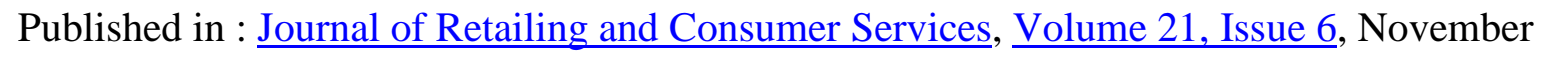
2014, Pages 976-991

DOI: 10.1016/j.jretconser.2014.08.018

\begin{abstract}
Whenever a retail company expands its store network in a foreign market, decisions have to be made about how this can be achieved. Existing studies of retail internationalization have usually analyzed the "entry mode" choice as an end in itself, and not as the start of a firm's international development. In addition, there is much debate in the academic literature about the antecedents for retail foreign operation mode choice and the relevance of generic internationalization theories to international retailing. Therefore, the objectives of this research are (1) to investigate the paths of entry and subsequent expansion modes pursued by retailers in international markets and (2) to develop and test a model of expansion mode antecedents in the light of generic business internationalization theories. This is achieved on the basis of data collected from 43 French fashion retailers and a PLS-SEM approach. Results show that (1) retailers clearly differentiate between entry and expansion modes; (2) the international marketing plan, the perceived attractiveness of the foreign market, and strategic and ownership conditions are the key antecedents for the choice of an expansion mode. After comparing the results with the explanations proposed by the generic internationalization theories, a multi-theoretical framework is proposed which draws from the Uppsala internationalization process model, network theory and the born-global theory. The findings provide a wealth of information for retailers' use in choosing appropriate foreign operation modes.
\end{abstract}

\section{Keywords}

Foreign operation mode, retail internationalization, internationalization theories, PLS-SEM, fashion retailing 


\section{Introduction}

Retailers are increasingly being challenged to operate and expand their store networks across borders and cultures (Deloitte, 2012; 2014a). Internationalization consumes significant amounts of management time, resources, and expertise, so retailers seek foreign operation modes that minimize risk and maximize the potential for success (Deloitte, 2009). The foreign operation mode (FOM) decision is a major concern in the international business literature, with a rich tradition of research into this question (e.g. Wind and Perlmutter, 1977; Welch et al., 2007). However, the issue remains under-researched in international retailing (Swoboda et al., 2009), despite it being recognized as a strategic decision with far-reaching implications for performance (Gielens and Dekimpe, 2001; Evans et al., 2008).

Existing studies have usually analyzed the "entry mode" choice as an end in itself, and not as the start of a firm's international development. Whilst retail internationalization is acknowledged as a dynamic and ongoing process (Alexander and Myers, 2000; Dawson, 2007), the FOM question is typically considered from a static perspective (Quinn and Alexander, 2002). In reality, retail companies tend to enter foreign markets initially through a small number of locations before progressively expanding their store networks over time. Consequently, when attempting to understand retailers' international strategies, examining how companies pursue their growth strategies once they have entered an international market becomes more important than only analyzing the initial entry mode choice. In this context, there is also still a need to understand the antecedents of retail FOM decisions and the extent to which they are consistent with those suggested by the generic internationalization theories. Indeed there is much debate about the applicability of these theories to retailing (Dawson, 1994; 2007; Wrigley et al., 2005).

Important issues in relation to FOM choice in retailing remain unaddressed in the literature and prompted this research. The overall aim of this paper is to examine FOM decisions in retailing in the light of the generalized internationalization theories. More specifically, the research purpose is two-fold: (1) to investigate the paths of entry, and subsequent expansion mode(s), pursued by retailers in international markets, and (2) to develop and test a model of expansion mode antecedents in the light of internationalization 
theories. In doing so, this paper contributes to the existing literature by (i) developing knowledge on the evolution of FOMs over time, and (ii) suggesting an overall framework for retail post-entry mode antecedents, at least for fashion retailers. Such a framework should facilitate retailers' decision making as it highlights when it is pertinent to choose one expansion mode over another. A final contribution of this paper arises from a discussion of how well generic internationalization theories help our understanding of retail expansion mode decisions.

The following section summarizes the theoretical background provided by existing research on the reasons for retail FOM evolution over time, and the antecedents for FOM choice. An empirical study conducted with French fashion retailers is then presented. Given the diversity of FOMs and the high degree of internationalization amongst fashion retailers, this sector provides a suitable frame in which to explore the dynamics of FOM choice. Subsequently, the main findings are presented, the key results are discussed, and an explanatory framework grounded in the generic internationalization theories is proposed. The article concludes with key implications for research and retail management and by identifying some promising directions for future research.

\section{Retailers' foreign operation mode decisions: the theoretical background}

A FOM can be defined as "the organizational arrangement that a company uses to conduct international business activities" (Benito et al., 2009: 1458). Given its influence on the success of the operation, it is a critical choice in how to operate abroad. Theoretically, options are plentiful. The store network may be managed from the domestic market or via a wholly-owned subsidiary or joint venture and may take the form of shop-in-shops, franchised stores, company-owned stores (flagship stores, pop-up stores or traditional stores) or concessions and licenses. Wholesale stockists and agents can also help support the physical store presence, as well as websites which can provide international visibility. The pros and cons of each individual FOM are well documented (Alexander and Doherty, 2009), as is their use in combination in plural forms (Quinn and Alexander, 2002; Perrigot et al., 2013) and, to a lesser extent, in multimodal forms (Waldman, 1978; Moore and Fernie, 2000; Petersen and 
Welch, 2002). FOMs are usually categorized according to the degree of control a parent company has over decisions (Anderson and Gatignon, 1986; Treadgold and Davis, 1988), and the amount of the parent company's own resources that are committed to the project (Hill et al., 1990; Gielens and Dekimpe, 2001). The degree of strategic flexibility each option offers i.e. the possibility to change FOM without incurring high switching or withdrawal costs (Driscoll and Paliwoda, 1997), and the degree of protection against the dissemination risk of the retailer's specific assets provide further grounds for categorization (Hill et al., 1990).

The case for a richer conceptualization of FOMs (Benito et al., 2009) has highlighted two topics of high relevance for retail internationalization: (i) the evolution of FOMs, suggesting a dynamic approach with possible mode changes or combinations in place over time; (ii) the antecedents of FOM decisions. General internationalization theories suggest various explanations for FOM dynamics and choices, but their relevance to the retailing sector is disputed (Vida and Fairhurst, 1998; Dawson, 2007).

\subsection{Foreign Operation Mode changes and dynamics}

A mode change means that a company decides to operate in a country with a FOM different from the one previously used (Swoboda et al., 2009). This may take the form of (i) mode switch i.e. shifting from one mode to another, (ii) mode stretch i.e. extending and expanding the use of an existing mode, or (iii) mode package i.e. combining a new FOM to enhance the utility and value of the initial FOM.

FOM change and the inherent dynamic are seldom addressed in retailing research, with the exception of Petersen and Welch (2000) and Quinn and Alexander (2002) who shed light on the switch to international retail franchising from other entry modes. They suggest that franchising is mainly used as an expansion mode rather than an entry mode because it recognizes learning benefits from previous experiences and it subsequently generates faster rates of growth. FOM changes over time may be all the more important in retailing since retailers often enter a new market cautiously, in a small number of locations, and then open new stores over time as they extend their store network's market coverage (Lafontaine and Leibsohn, 2005). A dynamic approach to further understand "what happens once entry mode choice has been made" seems to be needed (Canabal and White, 2008: 267). 
Explanations for FOM changes can be derived from the two main streams within the internationalization literature. On the one hand, the economic-strategic stream suggests that radical FOM changes occur only when there are drastic modifications in the circumstances pertaining to the operation (Welch et al., 2007). Internal and external contingencies impact upon the choice of degree of control, resource investment and flexibility, and lead to an increase or decrease in commitment depending on the type of change. From this perspective, the FOM dynamic consists in a series of static choices, where each decision is treated as a static phenomenon dictated by efficiency considerations and relative costs and benefits. The expansion mode is not directly related to the entry mode.

On the other hand, the behavioral stream suggests two explanations. First, from the Uppsala internationalization process perspective (Johanson and Vahlne, 1977; 1990), changes are unavoidable and have to be expected given the dynamic nature of the internationalization process. Changes are incremental depending on the experiential knowledge of the company. Initially, the range of FOMs considered is constrained because knowledge is limited but the way of operating in foreign markets changes as the company gains experience. Over time a company moves step by step towards higher commitment modes with appropriate experience and knowledge. From this perspective, the FOM dynamic consists of a sequence of steps by which companies acquire experience and knowledge about foreign markets through gradual commitment of resources and learning by doing. The expansion mode therefore enlarges the possibilities explored through the entry mode. Second, from the perspective of the network approach (Welch and Welch, 1996), the formal and informal business networks from which inward-outward connections emerge and develop influence the range of FOMs considered. High commitment modes can be chosen from entry if strong relationship networks exist. In the network perspective, the organic path-way is moderated by the relationship networks. Empirical evidence is mixed on how well these explanations of FOM dynamics apply to the retailing sector. From the internationalization process perspective, the expected sequential pattern of development is not always evident: retail companies often move directly to foreign investment (Moore, 1998; Vida, 2000; Vodlan and Vida, 2008); yet, knowledge transfer appears to be vital to the process (Jonsson and Foss, 2011). Likewise, despite difficulties in 
measuring retail internationalization through the lens of the economic-strategic theories, existing empirical studies do not support the view of static FOM choices independent of each other (Doherty, 1999; Huang and Sternquist, 2007).

\subsection{The antecedents of foreign operation mode choice}

The antecedents of FOM choice have received broad attention in the international business literature from different theoretical perspectives (Morschett et al., 2010) ${ }^{1}$. In parallel, research in international retailing has explored the antecedents of FOM choice mainly in an atheoretical manner (Picot-Coupey, 2009). It is therefore of interest to compare the antecedents observed in retailing to those proposed in international business in order to discuss potential connections. Such a comparison allows the identification of similarities, differences or linkages between the antecedents of entry and expansion mode selection.

\subsubsection{Explanations for FOM choice in the international business literature}

For the economic-strategic stream, the choice of a FOM is determined by the optimal degree of control over the foreign operation, given internal and external contingencies (Welch et al., 2007). From the behavioral approach, FOM choice is bounded by limited rationality and considerable perceived uncertainty. The choice relies on organizational learning and is influenced by a mix of external and internal factors. Each theoretical stream suggests a number of internal and external explanatory variables, which are summarized in table 1.

Table 1 goes about here

Overall, these antecedents of FOM choice cover different levels of analysis and encompass environment-specific (psychic or geographical distance, cultural differences, target market advantages), company-specific (resources, strategy, brand, product entrepreneurial orientation, knowledge, experience) or transaction-specific (tacit know-how) antecedents. Past research reveals heterogeneous results for each factor (Morschett et al., 2010). Reasons for such conflicting findings may be that FOM decisions are a function of different factors and their interactions. Such complex interdependencies are rarely taken into account. Moreover, the choice is dynamic but most studies do not differentiate between entry

\footnotetext{
${ }^{1}$ A synthesis of the literature is presented in appendix A.
} 
and expansion mode and do not explicitly look into individual decisions at each stage (Wrona and Trapczynski, 2012).

\subsubsection{Explanations for FOM choice in the retailing literature}

Simultaneously, a stream of exploratory research on FOM decisions in retailing provides insights into the antecedents governing this choice, although mostly independently from any underlying theoretical framework (Doherty, 2000; 2007; Hutchinson et al., 2006). The observed antecedents can be categorized into four key groups (Picot-Coupey, 2009). First, there is a consensus that factors related to the retail marketing policy (format, brand, location, assortment and market coverage strategy) are highly influential (Fernie et al., 1997; Doherty, 2000; Moore, 2000; Picot-Coupey, 2006; Park and Sternquist, 2008; Lu et al., 2011). FOM determines the extent to which a retail company is involved in designing and implementing marketing plans in the target market; therefore the nature of the marketing policy influences retail FOM decisions. Second, factors associated to the retailer's business strategy are important in retail FOM choice (Salmon and Tordjman, 1989; Dawson, 2001) as the FOM has to reconcile the growth strategy with the resources of the company. Third, retail company characteristics are important. Motives for internationalization, company size and experience are factors often discussed (Moore, 2000; Vodlan and Vida, 2008) but there is no consensus either on the nature or on the impact of their influence. In addition, networking - regarded as a facilitator of international development and a source of opportunism (Dawson, 2001) encourages retailers to choose more risky modes (Picot-Coupey, 2006; Elg et al., 2008). The top managers' degree of involvement in the internationalization process is said to shape FOM choices (Doherty, 2000). Fourth, the influence of factors relating to the host country and market environment is acknowledged (Gielens and Dekimpe, 2001; Evans et al., 2008; Vodlan and Vida, 2008) but debated: geographical or psychic distance is viewed as requiring either control or delegation. Overall, how these antecedents influence the final choice is unclear: the decision is complex, being the net result of various factors often with complementary but sometimes contradictory effects. Heterogeneous findings can also be attributed to the fact that most studies do not differentiate between the entry and expansion modes, yet the degree of influence of factors could be different at each stage. 
These antecedents for FOM choice observed in retailing research match most of the firm-specific (product characteristics, brand, international strategy, resources, network, experience) and environment-specific antecedents listed in the international business literature (table 1). Marketing factors play a more specific and prominent role in the case of retailing. Retail format, brand and product assortment have been identified as key specific assets of retailers (Moore, 2000; Goldman, 2001) - in effect they are the product or output of individual retail business models - which may explain the greater emphasis placed upon them.

\subsection{A conceptual model of retail expansion mode choice and hypotheses}

From the literature review of FOM dynamics and antecedents, we conclude that (i) the FOM decision has to be explicitly looked at as a distinct stage, and (ii) various factors in relation to firm characteristics and environment characteristics determine the appropriate choice of FOM.

We focus on the expansion mode and suggest a comprehensive framework of the antecedents that impact upon the expansion mode decision for retailers. Hence, a total of five expansion modes which are those most commonly used to develop store networks in a foreign market have been identified (Petersen and Welch, 2000; Alexander and Doherty, 2009) and are therefore considered in our model: store networks can be operated through: (1) companyowned stores; (2) franchised stores; (3) shop-in-shops; (4) a plural form associating franchised- and company-owned stores; and (5) a composite form combining shop-in-shops, franchised- and company-owned stores. The focus of the research is on stores as the dominant format of internationalization despite the growing importance of on-line presence in international markets. Each expansion mode option exhibits specific characteristics in terms of dissemination risk, control over decisions, resource commitment, and flexibility (Hill et al., 1990; Driscoll and Paliwoda, 1997). Our framework integrates the assessment of expected mode characteristics against mode antecedents. In doing so, our purpose is to overcome inconsistencies arising from the analysis of the direct influence of antecedents on FOM choice as a given antecedent may exercise contradictory effects on a given FOM (Driscoll and Paliwoda, 1997; Welch et al., 2007; Wrona and Trapczynski, 2012). Regarding antecedents, variables were directly selected from previous research results which have identified a number of factors at each time. These dispersed factors are integrated into an encompassing 
model. The antecedents include company-specific antecedents relating to marketing (Fernie et al., 1997); strategy (Salmon and Tordjman, 1989; Doherty, 2000); relationship networks (Elg et al., 2008) and managers' orientation towards internationalization (Doherty, 2000) as well as host environment-specific antecedents (Vodlan and Vida, 2008). Hence, the retailer's international marketing plan; its business strategy and ownership structure; and the perceived attractiveness of the foreign market, are hypothesized as explaining the FOM choice. Relationship networks and top managers' involvement in internationalization are hypothesized as moderators. These marketing, strategic, environmental, relational and entrepreneurial attitude antecedents are also noted in existing internationalization theories, as displayed in table 1. Figure 1 sets out our conceptual model which provides an integrated framework that conceptualizes multi-faceted antecedents pertaining to retail foreign expansion mode choice. Twelve interviews with international retail managers supported the development of the model and its underlying hypotheses.

Figure 1 goes about here

\subsubsection{Evolution of retail FOMs over time}

Discussion of the FOM concept highlighted its dynamic character. Whatever the reasons for the choice of a specific FOM, circumstances (market conditions, relationships, company context) are liable to change over time, which may lead to a perception that the initial mode should be altered in a certain way. Mode adjustments are driven by a mix of internal and external opportunities. Consequently, the market entry mode has to be distinguished from the market expansion mode, as the needs and priorities of the internationalizing company are likely to be different at each stage (Fischer et al., 2005). According to both the economic-strategic and behavioral streams of internationalization theory, retail companies may experience FOM changes; however they each suggest diverse internationalization paths, with different linkages between the entry mode and the expansion mode resulting in different FOM dynamics. The entry mode and expansion mode therefore need to be considered separately as well as in relation to each other. Thus:

\section{H1 - Retail companies use different modes for entry and expansion.}




\subsubsection{The international marketing plan}

The choice of expansion mode appears to be a decision that is connected to the retailer's international marketing policy, i.e. to the decisions regarding the underlying marketing strategy and retail format, product, service mix in a foreign country (Alexander and Doherty, 2009; Goldman, 2001). The expansion mode determines the context of implementation of the international marketing plan (Bradley and Gannon, 2000). An international marketing plan articulates an organization's overall marketing efforts, both in terms of international marketing strategy and international marketing mix. The retailer's marketing plan is grounded in retail positioning, and broadly speaking is associated either with functional or symbolic attributes (Morschett et al., 2006; Dolbec and Chebat, 2013). Positioning based on symbolic attributes typically requires an emotion-focused retail brand, supported by a specific brand image and a strategy of unchanged format transfer (Burt and Carralero-Encinas, 2000; Goldman, 2001). This corresponds to leveraging specific intangible assets through respect of the underlying retail concept (Moore, 2000). Such specific assets must be simultaneously disseminated and protected (Goldman, 2001; Dolbec and Chebat, 2013). Therefore, the dissemination risk of specific assets, that is to say the degree of risk perceived by a firm that a partner in a foreign market will appropriate its specific advantages (Hill et al., 1990), impacts upon the choice of an international expansion mode. Moreover, the international marketing plan could also influence expansion mode choice through the degree of control over decisions that the marketing approach necessitates. Thus:

$\boldsymbol{H} 2$ - An international marketing plan based on differentiation through symbols (versus differentiation based on functional attributes) results, for expansion mode choice,

H2.1 in a greater desire for protection against dissemination risk of specific assets;

H2.2 in a greater desire for control over decisions.

\subsubsection{The retail company's strategic and ownership profile}

The FOM directly interplays with the core business strategy of the retail company. Finding a way to achieve a sustainable competitive advantage is essential when elaborating a strategy. Competitive advantage in retailing stems from high levels of efficiency in the management of the retail network supported by cost control and supply chain optimization, from high levels 
of differentiation from competitors, or from different ways of combining both (Morschett et al., 2006). The ability of companies to pursue a business strategy is directly influenced by company ownership structure (Carney, 2005). Business strategy implementation has direct and interactive relationships with dominant ownership (Goodstein and Boeker, 1991; Gloden and Zajac, 2001). Such complex interdependencies have to be considered in order to better understand expansion mode antecedents (Welch et al., 2007; Wrona and Trapczynski, 2012). Therefore, the strategic and ownership profile construct captures the strategy of the retail company in relation to its perceived source of competitive advantage, and its ownership structure which is critical for strategy execution. The type of competitive advantage operated, combined with family business ownership or financial shareholder ownership, leads to the choice of one expansion mode over another, as requirements differ in terms of the appropriate degree of control and of the nature and amount of resources dedicated to the project (RamonRodriguez, 2002; Chang, 2007). Thus:

H3 - A strategic and ownership profile based on differentiation (versus cost optimization) and family ownership (versus financial shareholders ownership) results, for expansion mode choice,

H3.1 in a greater desire for control over decisions;

H3.2 in a lower desire for resource commitment.

\subsubsection{Perceived attractiveness of the foreign country}

Environmental determinants are considered as highly influential in FOM choice. Yet empirical results are inconsistent. Large geographical distance from the home market and high market potential have been observed as leading to either limited or greater resource commitment (Burt, 1993; Vodlan and Vida, 2008). The same dichotomy is evident in respect of the impact of psychic distance i.e. the differences in culture and business practices perceived by individuals between domestic and foreign markets (Evans et al., 2008; Vodlan and Vida, 2008). Analysis of the direct impacts of environmental antecedents on FOM choice have focused on isolated decisions and on a few selected factors, which may result in findings specific to a decision context (Wrona and Trapczynski, 2012). Environmental antecedents could consider a mix of objective and subjective criteria about the foreign country. Therefore, 
the combined effect of psychic distance and degree of attractiveness of the market is captured within the construct of perceived attractiveness of the foreign market. If the perceived degree of attractiveness is high, this could imply, for expansion mode choice, a higher level of resource commitment and a lower level of importance placed upon flexibility i.e. the ability to adapt the network rapidly with limited cost implications. During expansion, the target market may be perceived as promising, with no need to withdraw rapidly and with a willingness to commit in the market. Thus:

H4 - Important (versus limited) perceived attractiveness of the foreign country results, for expansion mode choice,

H4.1 in a greater desire for resource commitment;

H4.2 in a lower desire for flexibility.

\subsubsection{Involvement of top managers in internationalization}

Individual attitudes play an important role in FOM decisions (Wrona and Trapczynski, 2012). The involvement of top managers in internationalization reflects their attitudes, either favorable or unfavorable, towards international projects (Gençtürk et al., 1995). The intensity of interest from a senior retail manager in internationalization plans "contributes by emphasizing the importance of key personnel in shaping (...) the entry or the expansion mode choice" (Doherty, 2000: 234), suggesting that this factor acts as a moderator in FOM choice. A proactive attitude is seen as a factor likely to reduce the negative effect of a strategic and ownership profile based on differentiation and family control over resource commitments. In contrast, an unfavorable attitude towards internationalization is seen as a factor likely to accentuate approaches towards resource commitment minimization. Thus:

H5 - The involvement of top managers in internationalization decreases the negative effect of the strategic and ownership profile based on differentiation and family ownership on resource commitment.

\subsubsection{Relationship networks}

Relationship networks between a retail company and its stakeholders provide both better knowledge related to the target market, and access to the resources needed for expansion of 
the retail network in that foreign country (Elg et al., 2008). These networks provide a sense of familiarity which is influential in shaping perceptions of the attractiveness of the foreign market (Dawson, 2001; Picot-Coupey, 2006). The stronger the relationship networks, the more likely retail managers are to endorse a choice of an expansion mode requiring greater resources. Thus:

H6 - Relationship networks of retailers increase the positive effect of the perceived attractiveness of a foreign market on resource commitment.

\subsubsection{Foreign expansion mode options and their dimensions}

Antecedents result in desired expansion mode characteristics. The choice of a retail expansion mode is seen to be driven by considerations over the dissemination risk of specific assets; control over decisions; resource commitment; and flexibility, which are the dimensions along which FOMs are usually categorized (Anderson and Gatignon, 1986; Hill et al., 1990; Driscoll and Paliwoda, 1997). Managers analyze each mode alongside these considerations and choose the one which fits the best. The five most common modes to expand a store network in a foreign market can be assessed on these dimensions, as presented in table 2.

Table 2 goes about here

Company-owned stores provide the greatest protection of specific assets, as they are not entrusted to stakeholders (Fernie et al., 1997; Moore, 1998), and the greatest levels of control over decision making (Dawson, 1994). The resources committed in expansion plans via company-owned stores are however significant and flexibility is limited due to the costs of network adjustment (Moore, 2000). Thus:

H7- It is more likely for a retail company to expand its store network in a foreign market with company-owned stores if there is

H7.1 a greater desire for protection against dissemination risk of specific assets;

H7.2 a greater desire for control over decisions;

H7.3 a greater desire for resource commitment;

H7.4 a lower desire for flexiblity. 
Resource commitment minimization and high levels of flexibility are qualities justifying the choice of expanding a foreign store network through franchised stores. Yet difficulties have been experienced by retailers in controlling their foreign franchisees (Hutchinson et al., 2006). These control issues may be managed to some extent through the legal contract between partners (Pederzoli, 2006). However, the risk of disseminating the retailer's specific assets, especially marketing assets, exists (Quinn and Doherty, 2000), even if the franchising contract provides some legal protection (Watson et al., 2005). Thus:

H8-It is more likely for a retail company to expand its store network in a foreign market with franchised stores if there is

H8.1 a lower desire for protection against dissemination risk of specific assets;

H8.2 a lower desire for control over decisions;

H8.3 a lower desire for resource commitment;

H8.4 a greater desire for flexiblity.

Shop-in-shops require far fewer resources and offer greater flexibility because of the shortterm contract and limited investment required (Alexander and Doherty, 2009; Jerath and Zang, 2010). However, they also offer limited protection of the retail network's specific assets and limited control over operations due to the role of the retailer hosting the shops (Petersen and Welch, 2000; Hutchinson et al., 2006). Thus:

H9- It is more likely for a retail company to expand its store network in a foreign market with shop-in-shops if there is

H9.1 a lower desire for protection against dissemination risk of specific assets;

H9.2 a lower desire for control over decisions;

H9.3 a lower desire for resource commitment;

H9.4 a greater desire for flexiblity.

Plural networks are acknowledged as providing both local responsiveness and global adaptation (Botti et al., 2009). In an international perspective, this could allow some adaption of the retail concept to the local market whilst limiting the resource invested through the use of franchised units. Meanwhile company-owned units in the plural network could allow relative control over decisions. Thus: 
H10-It is more likely for a retail company to expand its store network in a foreign market with company-owned and franchised stores if there is

H10.1 a greater desire for protection against dissemination risk of specific assets;

H10.2 a greater desire for control over decisions;

H10.3 a lower desire for resource commitment;

H10.4 a greater desire for flexiblity.

The key benefit of combining company-owned stores, franchised stores and shop-in-shops in a composite form is a faster pace of expansion (Petersen and Welch, 2002): numerous units can be opened with limited investment. Yet, the dissemination risk of specific assets can be relatively high as they are shared with numerous and various partners (Moore, 2000). Thus:

H11- It is more likely for a retail company to expand its store network in a foreign market with company-owned stores, franchised stores and shop-in-shops if there is

H11.1 a lower desire for protection against dissemination risk of specific assets;

H11.2 a lower desire for control over decisions;

H11.3 a lower desire for resource commitment;

H11.4 a greater desire for flexiblity.

\subsubsection{Control variables}

We controlled the effect of several variables to account for alternative influences on foreign expansion mode decisions. First, following the behavioral approach, we controlled for experience and size. Second, considering prior research we controlled for the impact of the domestic operation mode on FOM choice (Benito et al., 2009).

\section{Methodology}

\subsection{Sample and data collection}

In order to investigate the path of entry and subsequent expansion mode and to test expansion mode antecedents, we conducted a questionnaire survey of the top managers of French fashion retail companies managing a minimum of 10 outlets abroad. To ensure high internal validity, the sample is French-based to control for country effect (De Mooij and Hofstede, 2002) and is sector-specific to control for sector effect (Laanti et al., 2007). We chose the 
French fashion retailing sector as it has developed a significant presence internationally over time (Deloitte, 2011; 2014b) and operates very diverse organizational structures (Chauday and Fadairo, 2010). Such organizational variety combined with a high international profile allowed observations of expansion decisions and FOM dynamics.

We derived a list of 210 French fashion retail companies operating internationally from various publications and directories ${ }^{2}$, cross-checked with the retailers' websites. Our key informants were the President, C.E.O. or top manager in charge of international operations. The unit of analysis consisted of one international (country) operation, not multiple ones. Respondents were asked to think about the most important international expansion decision they had recently been involved with and respond with reference to that experience. Questionnaires were first mailed, with three follow-up steps by e-mail and phone. This procedure resulted in 43 usable responses. Although a small number due to a narrow population, this corresponds to a response rate of 20.5 percent which is satisfactory when compared to previous research in international business (Ekeledo and Sivakumar, 2004; Krafft et al., 2004). The sample characteristics are presented in table 3.

\section{Table 3 goes about here}

The competence of the key informants to comment on the research question was checked by considering the respondent's position in the company, the length of her/his international experience, and the importance of her/his role in the decision. Of the 43 respondents, 39 of them were either the President, CEO or the top manager in charge of international development and the other four were in charge of the international operation under consideration; 35 had international experience of more than 5 years, and two-thirds of the respondents had played an "important" or "very important" role in the decision process. Consideration of potential non-response bias mainly involved comparisons between initial and late respondents, which is the standard method of evaluation when true values of the population parameters are unknown (Armstrong and Overton, 1977). The sample did not

\footnotetext{
${ }^{2}$ Retail yearbook Mode - Textile - Maison of the French Fashion Institute; yearbook of the French Federation of Franchise and Directory of the European Federation of International Retailers.
} 
suffer from response bias as no statistical difference was found when comparing early and late responses by testing with t-tests for group mean differences on each of the variables.

\subsection{Construct operationalization and measures}

To develop our measures, we undertook an extensive literature review and conducted 11 indepth interviews with international fashion retailers. Construct measures were all drawn from former studies yet adapted to our research context. Content analysis of the interviews helped refine both content specification and indicator specification, and structure the item list in the retail context. We used multi-item measures of FOM antecedents and FOM dimensions to take into account their multi-faceted character. The specification of the measurement models, either formative or reflective, followed the recommendations of Diamantopoulos and Winklhofer (2001), Rossiter (2002) and Jarvis et al. (2003).

The international marketing plan captures the marketing strategy and retail mix defined for a foreign market. It was measured by eight items adapted from Gannon (1993) and Bradley and Gannon (2000), referring to retail positioning, brand image, assortment, location, strategy of retail format transfer, and international marketing mix. These are different and non-interchangeable indicators covering all aspects of marketing strategy and retail mix. It implies that they form the construct, in line with Albers (2010). The retail company's strategic and ownership profile captures the competitive advantage the company takes advantage of, combined with its ownership structure. We used five items based on Contractor and Kundu (1998) and Ramon-Rodriguez (2002), referring to competitive advantage (economies of scale, logistic efficiency, critical size, image differentiation, vertical integration) to which we added one item about the ownership structure of the retail company. These items cover all facets of the construct and therefore are formative. The perceived attractiveness of the foreign market captures both objective and subjective aspects of foreign market attractiveness, namely market potential and psychic distance. We drew the market potential measure from Driscoll and Paliwoda (1997); this captures the upper limit of the total demand in the foreign market considering seven items referring to GDP per inhabitant, competition, geographic distance, sales potential, risk of counterfeiting and overall quality of country environment. We assessed the psychic distance, i.e. the perceived differences in business and 
cultural practices between the foreign market and the domestic market, through a six item scale drawn from Evans and Mavondo (2002). The involvement of top managers in internationalization captures the attitude, either favorable or unfavorable, the manager shows for international projects and was assessed through a five item scale taken from Gençtürk et al. (1995). Relationship networks, which capture the set of specific relationships developed by managers with various stakeholders, were measured taking as a base four items from Bell (1997) to which we added four items derived from our qualitative study. These indicators form the networks of relationships.

We followed the research tradition on the measurement of foreign expansion mode and its dimensions. Respondents were asked to describe the expansion mode used, and the information was then coded. We again drew from commonly used measures of FOM dimensions with items adapted to the retail context. Dissemination risk of specific assets captures the perceived threat of opportunistic partners appropriating the specific advantages of a company (Hill et al., 1990). Protection against such a risk was measured taking as a base the five items proposed by Hill et al. (1990) and Driscoll and Paliwoda (1997). Control over decision making refers to the authority over strategic and operational decision making (Hill et al., 1990; Treadgold and Davis, 1988). This was measured via six items based on Driscoll and Paliwoda (1997), to which we added two items on the control of brand image and of store window display. Resource commitment measures the amount of resources dedicated to the project that cannot be reorganized without costs (Hill et al., 1990). For this, we used four items proposed by Driscoll and Paliwoda (1997), and adapted to the retail context. As most of retailers express their concern in choosing a mode that involves minimal resource commitment, the scale items were worded accordingly. Finally, flexibility captures the ability to adapt quickly without incurring high costs (Driscoll and Paliwoda, 1997). The three indicators selected came from a scale proposed by Driscoll and Paliwoda (1997).

Constructs were validated by expert opinion, used as an alternative to multiple data collection and deemed appropriate with a small population (Hardesty and Bearden, 2004). Five experts judged the item relevance and assessed if the measures included all of the relevant attributes. Then, we analyzed the multi-dimensional structure of our constructs. 
The scales show high reliability as evidenced by the statistical criteria presented in table 4: Cronbach Alpha between 0.80 and 0.90; the Dillon-Glodstein Rho between 0.88 and 0.93 and the Average Variance Extracted between 64 and 77 percent. The factor analysis shows a strong factorial structure for the constructs, and suggests removing because of low factor loading one of the items initially suggested for dissemination risk, three of the items initially suggested for control over decision making, and one of the items initially suggested for involvement of top managers in internationalization. Discriminant validity was unsatisfactory for resource commitment and flexibility: a strong correlation between items existed. No empirical distinction was found between these two dimensions of an expansion mode. Flexibility appeared as a related consideration of resource commitment rather than a dimension in itself. It may be that, at the expansion stage, flexibility may be a less important dimension as the company considers the target market to be promising. Only one scale was validated; H4.2 and H7.4 - H11.4 regarding flexibility cannot be discussed separately.

\section{Table 4 goes about here}

Formative measurement models were assessed by evaluating (1) the relative magnitude of factor weights, which reflects indicator contribution to the construct, (2) the consistency of sign between weights and correlation, which is an indicator of nonmulticollinearity and by checking (3) the possible co-occurrence of positive and negative weights (Diamantopoulos et al., 2008; Cenfetelli and Bassellier, 2009). Results show the relevance of the indicators to their respective constructs except for two items of relationship networks. They also show differences in terms of sign between indicator weights and correlations, reflecting multi-collinearity due to conceptual overlap between collinear indicators. Five iterations finally generated stable coefficients for the four indices and suggested removing three of the indicator initially suggested for international marketing plan (product range, location and promotion correlated to positioning), two of those for strategic and ownership profile (image differentiation correlated to vertical integration; critical size to economies of scales), three of those for market potential (geographic distance correlated to risk of counterfeiting; sales potential; and legal environment to competitive intensity) and two 
of those for relationship networks (personal relationship correlated to suppliers relationships, and relationship with competitors to contacts with journalists). Each final formative variable shows minimal collinearity, with the Variance Inflation Factor (VIF) of all indicators ranging from 1.02 to 4.04 , far below the common critical value of 10 . The results lastly show cooccurrence of negative and positive indicator weights for five indicators neither suppressors nor collinear. Those indicators were then interpreted as having a negative effect when controlling for the influence of other indicators (Cenfetelli and Basselier, 2009). When the most important weight of a formative variable is negative, this leads to a reverse interpretation of the sign of the path coefficient (Chin et al., 2003; Cenfetelli and Bassellier, 2009). Overall, five scales and four indices were used which are displayed in Appendix B.

\subsection{Method}

To test our model, we used a Partial Least Squares structural equation model (PLS-SEM). This was particularly appropriate as it is perfectly suited to deal with small samples (Hair et al., 2012); complex causal models can be estimated (Hair et al., 2011); both reflective and formative variables can be easily incorporated (Diamantopoulos et al., 2008), and moderator effects can also be estimated (Chin et al., 2003). Data were analyzed with the SmartPLS 2.0 software (Ringle et al., 2009) following the specifications of Henseler et al. (2009) and Götz et al. (2010). Prior to this, a post-hoc power analysis on sample size was performed to make sure the study detected significant effects, using $G^{*}$ Power3 software (Faul et al., 2007). The power was found to be good, at 0.828 (alpha 0.05 - 2 tailed; number of predictor: 3 ; intermediate effect size) which is above the cut-off threshold of 0.80 .

\section{Results}

\subsection{The dynamics of retail foreign operation mode choice}

Table 5 displays the entry and expansion modes used by the French fashion retailers who responded to the questionnaire.

Table 5 goes about here

Nearly 40 percent (17) of companies entered a foreign market with shop-in-shops, 
whilst 32.6 percent (14) decided to create company-owned stores straight from the market entry stage. Furthermore, almost 40 percent (17) of expansion operations were based on company-owned stores. Fashion retailers are likely to open company-owned stores right from the entry stage, contradicting the view of incremental development in international markets. The conclusion of Vodlan and Vida (2008) is supported: the incremental commitment approach, posited by the internationalization process perspective, is not confirmed in retailing. By contrast, franchised stores appeared to be more attractive as an expansion mode than an entry mode. Such changes over time concur with the conclusions of Petersen and Welch (2000): franchising is a way to further expand in a foreign market once knowledge and competences have been acquired via another entry mode. Shop-in-shops were less frequently chosen to expand a store network than to create one.

Distinguishing the entry mode from the expansion mode appears to be appropriate since there is a statistically significant but moderate association (Cramer's $\mathrm{V}=0.536 ; \mathrm{p}=$ 0.000) [H1 supported]. While considering it, fashion retailers do not systematically pursue their in-country expansion with the mode initially chosen to enter the foreign market. Overall, internationalization initiated via franchised stores and $80 \%$ of those started via companyowned stores continued to use the same modes to expand, in contrast entry through shop-inshops switched to expansion via any mode. Evidence suggests that retailers experience mode switch, mode stretch and mode package. They clearly differentiate between entry mode (shopin-shops and/or company-owned stores) and expansion mode (franchised stores and/or company-owned stores) and experience varied internationalization paths. These results empirically corroborate the dynamic analysis of retail FOM decisions proposed by Vida and Fairhurst (1998) and Petersen and Welch (2000). In this context, investigating the drivers of retail expansion mode choice seems particularly relevant.

\subsection{Determinants of foreign expansion mode choice}

The results of the analysis with PLS-SEM are depicted in figure 2 and appendix C. The model goodness-of-fit is assessed for each endogenous variable through the coefficient of determination $\mathrm{R}^{2}$ : results are satisfactory.

Figure 2 goes about here 
The findings show the explanatory power of:

- the international marketing plan of the retail company [H2 supported]: an international marketing plan based on differentiation through symbols (brand, range uniqueness) results in a greater desire for protection against the dissemination risk of specific assets $\left(\mathrm{p}_{14}=0.485 ; \mathrm{p}=0.000\right)$ and for control over decisions $\left(\mathrm{p}_{15}=0.249 ; \mathrm{p}=0.008\right)$. These conclusions are consistent with previous results (Doherty, 2000; Moore, 2000; Jonsson and Foss, 2011): a key decision driver of a FOM lies in the potential to apply the international marketing plan efficiently. This is all the more important at the expansion stage when marketing decisions have to be consistently implemented across a growing store network.

- the strategic and ownership profile [H3 supported]: a strategic and ownership profile based on differentiation and family ownership results in a high desire for control over decisions $\left(\mathrm{p}_{25}=0.444 ; \mathrm{p}=0.000\right)$ and a high desire to minimize resource commitment $\left(\mathrm{p}_{26}=\right.$ -0.304; $\mathrm{p}=0.002)$. This result confirms previous conclusions suggesting that strategic and ownership considerations influence expansion mode decision (Sternquist, 1997; Doherty, 2000).

- the perceived attractiveness of the foreign market [H4.1 supported]: high perceived attractiveness of the foreign market results in a high desire for committing resources in the operation $\left(\mathrm{p}_{36}=0.308 ; \mathrm{p}=0.001\right)$. Considering both the psychic distance and the attractiveness of the market is a way to overcome the "paradoxes of psychic distance" (Evans and Mavondo, 2002). A retailer can perceive both a high attractiveness and a large psychic distance, the overall assessment leading to the choice of a resource-intensive mode.

In addition, two moderating effects are observed. The top managers' involvement in internationalization decreases to a limited extent $\left(\mathrm{f}^{2}=0.025\right)$ the negative effect of the strategic and ownership profile based on differentiation and family ownership on the amount of resources committed to the project [H5 supported]. The more involved in internationalization the top managers are, the more likely they are to favor approaches towards resource commitment in an expansion mode. However, it plays a less important role 
than observed in previous research (Moore, 2000; Quinn and Alexander, 2002). It may be that in an era of increasing internationalization or at the expansion stage, most senior managers are sensitive to this issue, so it no longer has an important moderator effect. The relationship networks built by retailers largely increase the positive effect of the perceived attractiveness of a foreign market on resource commitment $\left(\mathrm{f}^{2}=0.314\right)$ [H6 supported]. For a given perceived level of foreign market attractiveness, strong relationship networks result in higher resource commitment, confirming the importance of relationship networks in retail internationalization (Sparks, 1995; Elg et al., 2008).

The control variables (age, experience, domestic operation mode) were not statistically significant.

These determinants of expansion mode choice echo previous findings from the retailing literature (Doherty, 2000; Picot-Coupey, 2006), as well as results from the international business literature (Morschett et al., 2010). In particular, the impact of factors such as brand and positioning strategy is consistent with the results reported in a fashion context (Bridson and Evans, 2004; Lu et al., 2011). The antecedents influence the expansion mode decision through three dimensions along which the various modes are evaluated. The results point to the indirect relationships between FOM and the determinants, confirming the conclusions of Hill et al. (1990) and Driscoll and Paliwoda (1997). Results show the relative importance assigned to these three dimensions by fashion retailers for the expansion modes studied.

Company-owned stores are chosen as an expansion mode when the desire for protection against dissemination risk of specific assets is high $\left(\mathrm{p}_{47}=0.217 ; \mathrm{p}=0.001\right)$ and the willingness to limit resource commitment to the project is low $\left(\mathrm{p}_{67}=-0.391 ; \mathrm{p}=0.000\right)[\mathrm{H} 7.1$; H7.3 supported]. The control dimension has no significant impact [H7.2 not supported], which is surprising when compared to previous research conclusions (Dawson, 1994; Moore, 2000). It may be that measuring individual dimensions allows precise observation of their respective importance. As the dissemination risk dimension was rarely considered and measured in previous research, the control consideration may have been theoretically overestimated. Another possible explanation is that, at the expansion stage, control decisions 
are less important than preserving retail specific assets which are entrusted to a growing number of shareholders in the foreign market.

Franchised stores are chosen as an expansion mode when the desire for protection against dissemination risk of specific assets is moderate $\left(\mathrm{p}_{48}=0.153 ; \mathrm{p}=0.000\right)[\mathrm{H} 8.1$ not supported] and the desire to limit resources committed to the operation is high $\left(\mathrm{p}_{68}=0.271 ; \mathrm{p}=\right.$ 0.011) [H8.3 supported]. The financial rationale of international franchising is therefore supported (Quinn, 1998; Quinn and Doherty, 2000). Although inconsistent with traditional views (Quinn and Doherty, 2000), the positive relationship of dissemination risk with franchised stores can be justified by the argument of Watson et al. (2005) who state that a comprehensive franchise contract can protect a retailer's assets. The control dimension has no significant impact [H8.2 not supported], contradicting the views of Hutchinson et al. (2006).

Shop-in-shops are chosen as an expansion mode when the desire for protection against dissemination risk of specific assets is low $\left(\mathrm{p}_{49}=-0.285 ; \mathrm{p}=0.002\right)$ and the desire for control over strategic and operational decisions is also low $\left(\mathrm{p}_{59}=-0.389 ; \mathrm{p}=0.001\right)[\mathrm{H} 9.1$; H9.2 supported]. An unexpected result in the light of previous conclusions (Jerath and Zang, 2010) is the non-significant impact of the resource dimension [H9.3 not supported]. Resourcerelated issues can be less critical at the expansion stage than at market entry.

The plural form is chosen as an expansion mode when the desire for protection against dissemination risk of specific assets is moderate $\left(\mathrm{p}_{410}=0.119 ; \mathrm{t}=0.028\right)$, the desire for control over decisions is high $\left(\mathrm{p}_{510}=0.372 ; \mathrm{p}=0.001\right)$ and the desire to limit the resource committed to the operation is high $\left(\mathrm{p}_{610}=0.352 ; \mathrm{t}=0.002\right)$ [H10.1, H10.2, H10.3 supported]. Resource and control concerns are important in the choice of an expansion mode combining company-owned and franchised stores.

The composite form is chosen as an expansion mode when the desire for protection against dissemination risk of specific assets is very limited $\left(\mathrm{p}_{411}=-0.408, \mathrm{p}=0.014\right)$ and the desire for control is low ( $\left.\mathrm{p}_{511}=-0.362 ; \mathrm{p}=0.029\right)$ [H11.1, H11.2 supported]. Combining company-owned stores, franchised stores, and shop-in-shops is a powerful mode to develop a tight and balanced network, build a distinctive position and a strong brand image. The strength of these assets may self-protect the company and reinforce its ability to work with 
partners in the foreign market without incurring dissemination risk. The resource dimension has no significant impact [H11.3 not supported]. Retailers expanding with a composite form pursue ambitious objectives of development so the resource issue may be of minor importance.

\section{Discussion}

This research studied the dynamics of retail FOMs. The antecedents observed in previous research were organized into an integrative framework and tested, to investigate their influence on expansion mode choice in the French fashion sector. The results showed that (i) retailers clearly differentiated between entry and expansion modes; (ii) retailers associated company-owned stores as the FOM for expansion characterized by a high degree of protection of specific assets and requiring a willingness to commit resources; franchised stores provide moderate protection of specific assets and require limited resource commitment; shop-inshops provide limited protection of specific assets and limited control over decisions; plural forms provide moderate protection of specific assets, high control and require limited resource commitment and, finally, composite forms provide very limited protection of specific assets and low control; (iii) the international marketing plan, the strategic and ownership conditions and the perceived attractiveness of the foreign market were the key antecedents for the choice of an expansion mode while managers' involvement in internationalization and relationship networks moderated the choice.

We now discuss further these results alongside existing internationalization theories to assess if they are consistent with or deviate from the motives for the choices suggested by these generic theories. In other words, does this study provide evidence to support the generalized explanations found in internationalization theories in a retail context?

According to our sample of fashion retail managers, the expansion mode decision is the result of a dynamic process initiated from the entry stage: this conflicts with the economic-strategic perspective on internationalization but is consistent with the temporal perspective supported by the Uppsala internationalization process model (Welch et al., 2007). However, the expansion mode decision deviates from that suggested by this latter model as the incremental path is not verified, corroborating previous expectations (Vida and Fairhurst, 
1998; Vodlan and Vida, 2008). Industry-specific characteristics play an important role in this, especially the necessity to operate a full business system (Dawson, 2001).

We further examine each antecedent observed in our model in the light of internationalization theories. The expansion mode choice is implemented by consideration of the international marketing plan, the strategic and ownership conditions and the attractiveness of the foreign market as perceived by managers, rather than being determined by the size of the company and the length of its international experience. Such antecedents relating to marketing and strategic objectives, resources, foreign market and country environment and managers' perceptions are consistent with those proposed in the new behavioral internationalization theories - the born-global theory and the network theory - but conflict with the Uppsala internationalization process perspective. Besides, for fashion retailers, the relationship networks they develop play a facilitating role in assessing a foreign market and, as a consequence, help to speed up in-country expansion. This antecedent is considered a key issue in network theory (Coviello and Munro, 1997) and the Uppsala internationalization process model (Johanson and Vahlne, 2009). Finally, the involvement of top managers in internationalization echoes the views expressed in the new behavioral internationalization theories (i.e. the born-global theory and the network theory) on the role of personal attitudes in shaping the internationalization path (Welch and Welch, 1996; Laanti et al., 2007). Our results therefore support a multi-theoretical framework combining elements drawn from the Uppsala internationalization process model with the network theory and the born-global theory. Figure 3 shows how each of the antecedents observed in our model relates to a specific internationalization theory and proposes a formalized synthesis of explanatory and moderating variables and their theoretical roots.

Figure 3 goes about here

Overall, the results of our quantitative study of French fashion retailers suggest that a framework combining core concepts from the Uppsala internationalization process model, the network theory and the born-global theory contributes to improving our understanding of the expansion mode choice in an international retailing context. The antecedents for the choice of 
expansion mode can be appropriately explained from a multi-theoretical perspective: taken individually, each of the theories only considers a few of the antecedents. The idiosyncrasies of the retail sector in its internationalization process (Dawson, 1994) are more appropriately addressed by the so-called new theories of the internationalization process, whilst the Uppsala internationalization process model provides insights into the temporal dynamic of internationalization (Johanson and Vahlne, 2009; Jonsson and Foss, 2011). Thus, our results suggest that these theories may be considered to be complementary. They support the view of earlier research positing that the combination and integration of several internationalization theories provide a more appropriate explanation of FOM choice than single theories (Davies and Fergusson, 1995; Canabal and White, 2008; Lu et al., 2011). Despite specific challenges, generic internationalization theories can be meaningful in a retail context.

\section{Conclusion: implications, limitations and perspectives}

Distinguishing the entry mode from the expansion mode provides further insights into the growth process of retailers in foreign markets. Within the sector investigated, fashion retail companies develop additional locations via a mode that may be different from the one initially chosen to enter the foreign market, with a number of factors affecting entry and expansion decisions in various ways.

This research developed and tested an encompassing framework of the antecedents that influence the foreign expansion mode choice within a retail context. Such an empirical analysis helps evaluate the role of internationalization theories in retailing and overcomes some of the tensions over their application in this sector, as suggested by Dawson (2007) and Jonsson and Foss (2011). This research proposed a new multi-theoretical framework for expansion mode choice, following discussion of how each part of the results was consistent with each theory. The contribution of this article to the literature on retail internationalization is three-fold: (i) it enhances empirical observations of the dynamics of retail FOM choice; (ii) it allows a better understanding of the antecedents of retail expansion mode choice by considering an enlarged range of alternatives (five expansion modes) and numerous and interacting selected antecedents; (iii) it confronts the results relating to retail expansion mode 
antecedents alongside existing theoretical perspectives, thus grounding the proposed framework and offering an encompassing view of retail international activities. It also develops complementary approaches which make it possible to grasp the complexity of the factors influencing retail internationalization, including the FOM decision.

How can retailers benefit from these findings when they select a foreign expansion mode? This research has observed the dynamics of retail FOMs over time and the interdependencies between the entry and the subsequent expansion modes. Consequently, an entry mode in a foreign market has to be chosen with regard to the potential expansion modes in the future. This research has identified the key factors justifying the choice of one foreign expansion mode over another and when it is preferable to use particular post-entry modes. Each operation in a given foreign market is specific: as a consequence, an appropriate mode can be selected only on the basis of a structured diagnosis. The systematic use of the same mode is not efficient. Mode evaluation is a complex exercise. For retail managers in charge of international development, identifying the reasons influencing FOM choices allows them to focus on a number of key factors which they should consider when organizing their international expansion. Considering our results, retail managers should first evaluate their objectives in terms of dissemination risk minimization, willingness to control decision making, and degree of resource commitment regarding their international marketing plan, their business strategy and the foreign market context. An evaluation of the FOM characteristics alongside these objectives would then help them determine the most appropriate expansion mode. For example, considering its objectives, a retail company that is concerned to minimize dissemination risk and which can commit resources to the operation should favor companyowned stores as a foreign expansion mode. If the company is less concerned by dissemination risk issues but constrained by resources, its choice process should lead it to favor franchised stores or, if control issues are important, a plural form. Conversely, when the assessment of objectives against mode characteristics requires neither high protection of specific assets nor high control over decisions, a composite form should be favored. Moreover, the results highlight that relationship networks facilitate the decision making process when it comes to choosing the expansion mode. Networking is key to retail managers' international activities. 
The contribution of this research cannot be considered without highlighting its limitations. One relates to the sample size: stemming from only one sector and one country, as a consequence of the efforts to limit sources of variability and improve internal validity with an homogeneous population. Nevertheless, this research is one of the first to examine the expansion mode choice with primary data from senior managers through a causal perspective, rather than an exploratory one.

The study's findings, as well as its limitations, provide several opportunities for further research, especially into foreign expansion mode changes and adjustments. Future work is also needed to improve the external validity of the results. Research might be extended to other retail sectors as patterns and processes in internationalization may be different for fashion retailers or grocery retailers. The study might also be replicated with retail companies from countries other than France, as country effects have been documented in previous studies. Such cross-sector and cross-culture studies on entry and expansion mode decisions may open promising avenues for retail research. 
Appendix A- Internationalization Theories and Foreign Operation Mode Choice: a literature synthesis

\begin{tabular}{|c|c|c|c|}
\hline & & Key propositions & Explanations for FOM choice \\
\hline \multirow{5}{*}{ 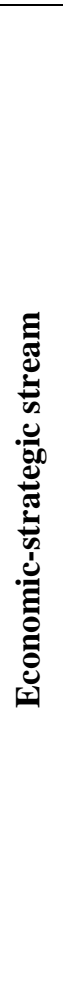 } & $\begin{array}{l}\text { Transaction cost analysis } \\
\text { and the new theories of the } \\
\text { firm (1) }\end{array}$ & $\begin{array}{l}\text { Normative analysis with an } \\
\text { efficiency rationale, "market or } \\
\text { hierarchy" choice }\end{array}$ & $\begin{array}{l}\text { Optimal choice based on a trade-off } \\
\text { between transaction costs and } \\
\text { internalization costs }\end{array}$ \\
\hline & $\begin{array}{l}\text { Dunning's eclectic } \\
\text { paradigm } \\
\text { (2) }\end{array}$ & $\begin{array}{l}\text { Holistic framework that draws } \\
\text { together firm-specific and market- } \\
\text { specific factors and suggests a } \\
\text { theory of international production }\end{array}$ & $\begin{array}{l}\text { Trade-off between Ownership, } \\
\text { Localization and Internalization } \\
\text { (OLI) characteristics to choose the } \\
\text { appropriate FOM }\end{array}$ \\
\hline & $\begin{array}{l}\text { Strategic approach of the } \\
\text { firm } \\
(3)\end{array}$ & $\begin{array}{l}\text { Pragmatic vision of the } \\
\text { internationalization process with a } \\
\text { focus on competition and } \\
\text { corporate strategic needs; } \\
\text { importance of strategic objectives } \\
\text { in driving the firm }\end{array}$ & $\begin{array}{l}\text { Contingent choice under the } \\
\text { constraint of managers' perceptions } \\
\text { and attitudes; best fit between a firm, } \\
\text { an industry and the environment in } \\
\text { which it operates }\end{array}$ \\
\hline & $\begin{array}{l}\text { Resourced-based theory } \\
\text { (4) }\end{array}$ & $\begin{array}{l}\text { Financial and managerial } \\
\text { resources as a determining factor } \\
\text { and an outcome of the } \\
\text { internationalization process }\end{array}$ & $\begin{array}{l}\text { Resource availability as the } \\
\text { determinant of the set of possible } \\
\text { FOMs }\end{array}$ \\
\hline & $\begin{array}{l}\text { Organizational capability } \\
\text { perspective } \\
\text { (5) }\end{array}$ & $\begin{array}{l}\text { Evolutionary theory of the } \\
\text { multinational corporation; firm } \\
\text { specializing in the transfer and } \\
\text { recombination of knowledge }\end{array}$ & $\begin{array}{l}\text { FOM as a conduit that can best } \\
\text { transfer the resources and } \\
\text { capabilities of the firm to the foreign } \\
\text { market; } \\
\text { imperfect imitability, i.e. degree of } \\
\text { implicit knowledge as a determinant } \\
\text { of the FOM choice }\end{array}$ \\
\hline \multirow{3}{*}{ 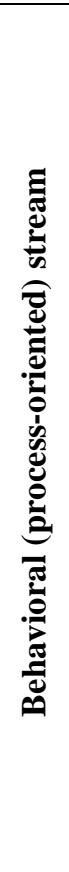 } & $\begin{array}{l}\text { Uppsala } \\
\text { internationalization process } \\
\text { model } \\
(6)\end{array}$ & $\begin{array}{l}\text { Incremental approach: } \\
\text { internationalization as a function } \\
\text { of a firm's experience and } \\
\text { learning process, which } \\
\text { progressively reduces the psychic } \\
\text { distance effect }\end{array}$ & $\begin{array}{l}\text { Stages approach from indirect to } \\
\text { direct FOMs because of increasing } \\
\text { confidence } \\
\text { Link between a firm's specific } \\
\text { factors - resources and experience } \\
\text { - and the FOM used to enter foreign } \\
\text { markets }\end{array}$ \\
\hline & $\begin{array}{l}\text { Network theory } \\
\text { (7) }\end{array}$ & $\begin{array}{l}\text { Network of relationships as a } \\
\text { determinant of the } \\
\text { internationalization process } \\
\text { because of the vital information it } \\
\text { contains; firm's success in } \\
\text { international ventures dependent } \\
\text { on its position in networks }\end{array}$ & $\begin{array}{l}\text { Through network contacts, FOM } \\
\text { choice is shaped by a set of } \\
\text { relationships (with customers, } \\
\text { suppliers, ...) because of the access } \\
\text { to resources they secure }\end{array}$ \\
\hline & $\begin{array}{l}\text { Born global theory } \\
\text { (8) }\end{array}$ & $\begin{array}{l}\text { Internationalization, almost from } \\
\text { the inception, influenced by } \\
\text { managers' attitude toward } \\
\text { internationalization, the firm's } \\
\text { strategy and resources, as well } \\
\text { as its absorptive capacity with } \\
\text { regard to internationalize }\end{array}$ & $\begin{array}{l}\text { More aggressive learning, } \\
\text { importance of speed of } \\
\text { development and, hence, a more } \\
\text { risky approach to the choice of FOM }\end{array}$ \\
\hline \multicolumn{2}{|c|}{$\begin{array}{l}\text { Multi-theoretical approaches } \\
\text { (9) }\end{array}$} & $\begin{array}{l}\text { Combining various theories to } \\
\text { suggest an integrated } \\
\text { framework of the } \\
\text { internationalization process }\end{array}$ & $\begin{array}{l}\text { FOM choice explained by the factors } \\
\text { considered in the selected theoretical } \\
\text { approaches }\end{array}$ \\
\hline
\end{tabular}

(1): Anderson and Gatignon, 1986; Burton et al., 2000; (2): Agarwal \& Ramaswami, 1992; Driscoll \& Paliwoda, 1997 (3): Root, 1994; (4) Erramilli et al., 2002 (5): Kogut and Zander, 1993; Erramilli et al., 2002; (6): Johanson and Vahlne, 1977; 1990; 2009; (7): Welch and Welch, 1996; Coviello and Munro, 1997; (8): Sharma and Blomstermo, 2003; Chetty and Camphell-Hunt, 2004; Laanti et al. (2007) (9): Malhotra et al., 2003; RamonRodriguez, 2002. 


\section{Appendix B - Measurement scales and indices}

\section{Scale items}

All measured on a five-point Likert Scale: $1=$ strongly disagree 5= strongly agree

\section{DISSEMINATION RISK}

In this foreign market, our company has chosen the expansion mode (XX) because it

\begin{tabular}{|l|l|}
\hline DR 1 & limits the risk of collections being imitated \\
\hline DR2 & limits the risk of partners appropriating our marketing know-how \\
\hline DR4 & limits the risk of partners appropriating our management know-how \\
\hline DR5 & it ensures that the concept will be respected in the market \\
\hline
\end{tabular}

\section{CONTROL OVER DECISION MAKING}

In this foreign market, our company has chosen the expansion mode (XX) because it provides

\begin{tabular}{|l|l|}
\hline CT2 & control over all decisions on strategic positioning \\
\hline CT3 & control over the store window display \\
\hline CT4 & $\begin{array}{l}\text { control over the work in the stores } \\
\text { scoring) }\end{array}$ \\
\hline CT5 & $\begin{array}{l}\text { delegation to local partners of decisions related to the merchandising of the products in the } \\
\text { stores (reverse scoring) }\end{array}$ \\
\hline CT7 &
\end{tabular}

\section{RESOURCE COMMITMENT}

In this foreign market, our company has chosen the expansion mode (XX) because

\begin{tabular}{|l|l|}
\hline RC1 & the financial resources invested in the market are limited \\
\hline RC2 & it limits the number of employees in the stores \\
\hline FX3 & it provides the possibility of withdrawing from the market quickly without high costs \\
\hline INVOLVEMENT OF TOP MANAGERS IN INTERNATIONALIZATION \\
\hline I1 & $\begin{array}{l}\text { our management committee considers that activities in foreign markets have a positive impact } \\
\text { on the financial results of our company }\end{array}$ \\
\hline I2 & $\begin{array}{l}\text { our management committee considers that international expansion has a positive impact on } \\
\text { company growth } \\
\text { our management committee shows no intention of further developing foreign activities } \\
\text { I4 }\end{array}$ \\
\hline I5 & $\begin{array}{l}\text { Expansion in foreign markets is considered as a waste of resources by the management } \\
\text { committee }\end{array}$ \\
\hline
\end{tabular}




\section{Indices indicators}

\begin{tabular}{|c|c|}
\hline \multicolumn{2}{|c|}{ INTERNATIONAL MARKETING PLAN OF THE RETAIL COMPANY(list questions) } \\
\hline Mk10 & The brand is positioned in France: with a low price \& discount image / as a high-end brand \\
\hline Mk14 & $\begin{array}{l}\text { The image associated with "styled-in France" or "made-in France" or "Paris" is a key element of } \\
\text { our marketing strategy in foreign markets. }\end{array}$ \\
\hline Mk22 & $\begin{array}{l}\text { The company sells store brands: yes, for the whole range of the assortment/ yes, for the main } \\
\text { part of the assortment }\end{array}$ \\
\hline Mk41 & In general, the network develops the same positioning strategy in France and in foreign markets. \\
\hline Mk42 & $\begin{array}{l}\text { Depending on the characteristics of the different markets, certain aspects of our marketing mix } \\
\text { are adapted }\end{array}$ \\
\hline \multicolumn{2}{|c|}{ STRATEGIC AND OWNERSHIP PROFILE (five-point Likert scale; $1=$ strongly disagree $5=$ strongly agree) } \\
\hline \multicolumn{2}{|c|}{ How important are the following factors for the general strategy of your company? } \\
\hline Pf12 & Economies of scale \\
\hline Pf14 & Quality of the logistics chain \\
\hline Pf15 & Vertical integration (monitoring of production and retailing) \\
\hline Pfc1 & $\begin{array}{l}\text { Your company is a family-controlled company / a listed company / a company with a financial } \\
\text { investor }\end{array}$ \\
\hline \multicolumn{2}{|c|}{$\begin{array}{l}\text { PERCEIVED ATTRACTIVENESS OF THE FOREIGN MARKET } \\
\text { Psychic distance (five-point Likert scale; } 1=\text { very different } 5=\text { very close) } \\
\text { How do you perceive this foreign country as different or close from France in terms of }\end{array}$} \\
\hline Dy1 & legal and political environment \\
\hline Dy2 & economic environment \\
\hline Dy3 & cultural environment \\
\hline Dy4 & language \\
\hline Dy5 & work relations \\
\hline Dy6 & business practices \\
\hline \multicolumn{2}{|c|}{ Market potential (five point semantic differential rating scales) } \\
\hline Av1 & GDP per inhabitant \\
\hline Av4 & competitive intensity \\
\hline Av5 & local competition \\
\hline Av7 & risk of counterfeiting \\
\hline \multicolumn{2}{|c|}{$\begin{array}{l}\text { RELATIONSHIP NETWORKS OF THE FIRM (five-point Likert scale; } 1=\text { strongly disagree } 5=\text { strongly agree ) } \\
\text { In this foreign country, the choice of this expansion mode was considered because }\end{array}$} \\
\hline R13 & of contacts established with professionals from the real estate sector \\
\hline R14 & of contacts established with journalists in this country \\
\hline R17 & our company has manufacturing plants in this country \\
\hline R18 & our company has suppliers in this country \\
\hline
\end{tabular}




\section{Appendix C - Bootstrap results on the structural model}

\begin{tabular}{|l|c|c|c|c|}
\hline & $\begin{array}{c}\text { Original } \\
\text { Sample }\end{array}$ & Sample Mean & Standard Dev. & t Statistics \\
\hline imp->ctrl & 0,249 & 0,287 & 0,1147 & $2,16^{* *}$ \\
imp->dmr & 0,485 & 0,524 & 0,1075 & $4,51^{*}$ \\
\hline sop->ctrl & 0,444 & 0,435 & 0,0747 & $5,95^{*}$ \\
sop->rc & $-0,304$ & $-0,306$ & 0,1037 & $2,93^{*}$ \\
\hline pafm->rc & 0,308 & 0,364 & 0,0981 & $3,14^{*}$ \\
\hline ctrl->cos & 0,046 & 0,052 & 0,1488 & 0,31 \\
ctrl->franc & $-0,177$ & $-0,171$ & 0,1228 & 3,44 \\
ctrl->shop- & $-0,389$ & $-0,395$ & 0,1190 & $3,29 *$ \\
ctrl->plural & 0,372 & 0,366 & 0,1130 & $1,97 * *$ \\
ctrl->compo & $-0,362$ & $-0,354$ & 0,2270 & $3,44^{*}$ \\
\hline rc->cos & $-0,391$ & $-0,391$ & 0,1130 & 0,73 \\
rc->franc & 0,271 & 0,277 & 0,1140 & $3,07^{*}$ \\
rc->shop- & $-0,050$ & $-0,055$ & 0,0680 & 0,66 \\
rc->plural & 0,352 & 0,349 & 0,1100 & $3,65^{*}$ \\
rc->compo & $-0,057$ & $-0,052$ & 0,1680 & $3,34^{*}$ \\
\hline dr->cos & 0,217 & 0,208 & 0,1170 & $3,13^{*}$ \\
dr->franc & 0,153 & 0,153 & 0,0997 & $1,97^{* *}$ \\
dr->shop- & $-0,285$ & $-0,279$ & 0,0910 & $2,28^{* *}$ \\
dr->plural & 0,119 & 0,126 & 0,0630 & $i n d i c a t$ \\
dr->compo & $-0,408$ & $-0,408$ & 0,1793 & $p a r a m$ \\
\hline
\end{tabular}

* (**) Significant coefficient. Values of Student's $t$ test greater than $|2.575|(|1.960|)$ indicate parameters significant at $1 \%(5 \%)$.

\section{Legend:}

imp: international marketing plan

sop: strategic and ownership profile

pafm: perceived attractiveness of the foreign market

ctrl: control over decision making

rc: resource commitment

dr: dissemination risk cos: company-owned stores

franc: franchise stores

shop-: shop-in-shops

plural: plural form

compo: composite form 


\section{References}

Agarwal, S., Ramaswami, S.N., 1992. Choice of foreign market entry mode: impact of ownership, location and internalization factors. Journal of International Business Studies 23 (1), 1-27.

Albers, S., 2010. PLS and Success Factor Studies in Marketing. In: Esposito-Vinzi V., Chin W., Henseler J., Wang H. (Eds), Handbook of Partial Least Squares Concepts, Methods and Applications, Springer, Berlin.

Alexander, N., Doherty, A.M., 2009. International Retailing, Oxford University Press, Oxford.

Alexander, N., Myers, H., 2000. The retail internationalisation process. International Marketing Review 17 (4/5), 334-353.

Anderson, E., Gatignon, H., 1986. Modes of foreign entry: a transaction cost analysis. Journal of International Business Studies 17 (3), 1-26.

Armstrong, J.S., Overton, T.S., 1977. Estimating non response bias in mail surveys. Journal of Marketing Research 14 (3), 396-402.

Bell, J.H.J., 1997. Control and ownership in international joint ventures. In Loughborough University (Eds), Proceedings of the British Academy of Management Conference, Loughborough: British Academy of Management, 56-73.

Benito, G., Petersen, B., Welch, L.S., 2009. Towards more realistic conceptualisations of foreign operation modes. Journal of International Business Studies 40 (9), 1455-1470.

Botti, L., Bric, C., Cliquet, G., 2009. Plural forms versus franchise and company-owned systems. A DEA approach of hotel chain performance. Omega 37, 566-578.

Bradley, F., Gannon, M., 2000. Does the Firm's Technology and Marketing Profile Affect Foreign Market Entry?. Journal of International Marketing 8 (4), 12-36.

Bridson, K., Evans, J., 2004. The secret to a fashion advantage is brand orientation. International Journal of Retail and Distribution Management 32 (8/9), 403-411.

Burt, S. L., 1993. Temporal trend in the internationalisation of British Retailing. International Review of Retail, Distribution and Consumer Research 3 (4), 391-410.

Burt, S.L., Carralero-Encinas, J. 2000. The role of store image in retail internationalization. International Marketing Review, 17 (4-5), 433-453.

Burton, F., Cross, A.R., Rhodes, M., 2000. Foreign market servicing strategies of UK franchisors: An empirical enquiry from a transaction cost perspective. Management International Review 40 (4), 373-400.

Canabal, A., White, G., 2008. Entry mode research: past and future. International Business Review 17 (3), $267-$ 284.

Carney, M., 2005. Corporate governance and competitive advantage in family-controlled firms. Entrepreneurship Theory and Practice 29 (3), 249-265.

Cenfetelli, R. T., Basselier, G., 2009. Interpretation of Formative Measurement in Information Systems Research. MIS Quarterly 33 (4), 689 - 707.

Chang, J., 2007. Ownership structure, diversification strategy and performance: implications for Asian emerging market multinational enterprises. International Finance Review 7 (3), 125-148.

Chauday M., Fadairo M., 2010. Contractual design and networks performance: empirical evidence from franchising. Applied Economics 42 (4), 529-533.

Chetty, S., Camphell-Hunt, C. 2004. Strategic approach to internationalization: a traditional versus a "born global" approach. Journal of International Marketing 12 (1), 57-81.

Chin, W.W., Marcolin, B., Newsted, P.R., 2003. A Partial Least Squares Latent Variable Modeling Approach for Measuring Interaction Effects: Results from a Monte Carlo Simulation Study and an Electronic-Mail Emotion / Adoption Study. Information Systems Research 14 (2), 189-217.

Contractor, F., Kundu, S., 1998. Franchising versus Company-Run Operations: Modal Choice in the Global Hotel Sector. Journal of International Marketing 6 (2), 28-53.

Coviello, N., Munro, H., 1997. Network relationships and the internationalization process of Small Software Firms. International Business Review 6 (4), 361-386.

De Mooij, M., Hofstede, G., 2002. Convergence and divergence in consumer behavior: implications for international retailing. Journal of Retailing 78 (1), 61-69.

Davies, G., Fergusson, F., 1995. The International Activities of Japanese Retailers. The Service Industries Journal 15 (4), 97-117.

Dawson, J., 1994. Internationalisation of Retailing Operations. Journal of Marketing Management 10 (4), $267-$ 282.

Dawson, J., 2001. Strategy and Opportunism in European Retail Internationalization. British Journal of Management 12 (4), 253-266.

Dawson, J., 2007. Scoping and conceptualising retailer internationalization. Journal of Economic Geography 7 (4), 1-26. 
Deloitte, 2009. International retailing - Finding growth in challenging times, Deloitte, London.

Deloitte, 2011. Leaving Home, Global powers of retailing 2011, Deloitte, London.

Deloitte, 2012. Switching channels, Global powers of retailing 2012, Deloitte, London.

Deloitte, 2014a. Retail Beyond begins, Global powers of retailing 2011, Deloitte, London.

Deloitte, 2014b. The path to 2020 Taking the long view of retail market entry, Deloitte, London.

Diamantopoulos, A., Winklhofer, H.M., 2001. Index Construction with Formative Indicators: An Alternative to Scale Development. Journal of Marketing Research 38 (5), 269-277.

Diamantopoulos, A; Riefler, P., Roth, K.P., 2008. Advancing formative measurement models. Journal of Business Research 61 (12), 1203-1218.

Doherty, A.M., 1999. Explaining international retailers' market entry mode strategy: internalization theory, agency theory and the importance of information asymmetry. The International Review of Retail, Distribution and Consumer Research 9 (4), 379-402.

Doherty, A.M., 2000. Factors influencing International Market Entry Mode Strategy: Qualitative Evidence from the UK Fashion Sector. Journal of Marketing Management 16 (1), 223-245.

Doherty, A.M., 2007. The Internationalisation of Retailing: Factors Influencing the Choice of Franchising as a Market Entry Strategy. International Journal of Service Industry Management 18 (2), 184-205.

Dolbec, P.Y., Chebat, J.C. 2013. The Impact of a Flagship vs. a Brand Store on Brand Attitude, Brand Attachment and Brand Equity. Journal of Retailing 89 (4), 460-466.

Driscoll, A. M., Paliwoda, S.J., 1997. Dimensionalizing International Entry Mode Choice. Journal of Marketing Management 13 (1/3), 57-87.

Ekeledo, I., Sivakumar, K., 2004. International market entry mode strategies of manufacturing firms and service firms: a resource-based perspective. International Marketing Review 21 (1), 68-101.

Elg, U., Ghauri, P., Tarnovskaya, V., 2008. The role of networks and matching in market entry of emerging retail markets. International Marketing Review 25, 6, 674-699.

Erramilli, M.K., Agarwal, S., Dev, S.C., 2002. Choice between Non-Equity Entry Modes: an Organizational Capability perspective. Journal of International Business Studies 33 (2), 223-242.

Evans, J., Mavondo, F., 2002. Psychic Distance and Organizational Performance: An Empirical Examination of International Retailing Operations. Journal of International Business Studies 33 (3), 515-532.

Evans, J., Mavondo, F., Bridson, K., 2008. Psychic distance: antecedents, retail strategy implications and performance outcomes. Journal of International Marketing 16 (2), 32-63.

Faul, F., Erdfelder, E., Lang, A.-G., Buchner, A., 2007. G*Power 3: A flexible statistical power analysis program for the social, behavioral, and biomedical sciences. Behavior Research Methods 39 (2), 175-191.

Fernie, J., Moore, C. M., Lawrie, A., Hallsworth, A., 1997. The internationalization of the high fashion brand: the case of central London. Journal of Product and Brand Management 6 (3), 151-162.

Fischer, M., Clement, M., Shankar, V., 2005. International Market Entry Strategy: A Source of Late Mover Advantage?. Marketing Science Institute Report No. 05-118, Cambridge, MA.

Gannon, M., 1993. Towards a composite theory of foreign entry mode choice: the role of marketing strategy variables. Journal of Strategic Marketing 1 (1), 41-54.

Gençtürk, E., Childers, T., Ruekert, R., 1995. International Marketing Involvement: The Construct, Dimensionality and Measurement. Journal of International Marketing 3 (4), 11-37.

Gielens, K., Dekimpe M., 2001. Do international entry mode decisions of retail chains matter in the long run?. International Journal of Research in Marketing 18 (3), 235-259.

Golden, B.R., Zajac, E.J., 2001. When Boards Influence Strategy? Inclination x Power = Strategic Change. Strategic Management Journal 22 (12), 1087-1111.

Goldman, A., 2001. The transfer of retail formats into developing economies: the case of China. Journal of Retailing 77 (2), 221-242.

Goodstein, J.G., Boeker, W.B., 1991. Turbulence at the top: A new perspective on Governance Structure Changes and Strategic Change. Academy of Management Journal 34 (2), 206-330.

Götz, O., Liehr-Gobbers, M., Krafft,. K., 2010. Evaluation of Structural Equation Models using the Partial Least Squares (PLS-) Approach. In: Esposito-Vinzi, V., Chin, W., Henseler, J., Wang H. (Eds), Handbook of Partial Least Squares. Springer, Berlin, 691-712.

Hair, J., Ringle, C., Sarstedt, M., 2011. PLS-SEM: indeed a silver bullet. Journal of Marketing Theory and Practice 19 (2), 139-151.

Hair, J., Sarstedt, M., Ringle, C.M., Mena, A., 2012. An Assessment of the Use of Partial Least Squares Structural Equation Modeling in Marketing Research. Journal of the Academy of Marketing Science 40 (3), 414-433.

Hardesty, D.M., Bearden, W.O., 2004. The use of expert judges in scale development - Implications for improving face validity of measures of unobservable constructs. Journal of Business Research 57 (2), 98-107. 
Henseler, J., Ringle, C., Sinkovics, R., 2009. The use of Partial Least Squares path modeling in international marketing. In: Sinkovics, R., Ghauri, P., (Eds), New Challenges to International Marketing, Emerald JAI Press, Bingley, 227-319.

Hill, C.W.L., Hwang, P., Kim, C., 1990. An Eclectic Theory of the Choice of International Entry Mode. Strategic Management Journal 11 (2), 117-128.

Huang, Y., Sternquist, B., 2007. Retailers' foreign market entry decisions: an institutional perspective, International Business Review 16 (5), 613-629.

Hutchinson, K., Quinn, B., Alexander, N., 2006. SME retailer's internationalization: case study evidence from British retailers. International Marketing Review 23 (1), 25-53.

Jarvis, C. B., MacKenzie, S. B., Podsakoff, P. M., 2003. A Critical Review of Construct Indicators and Measurement Model Misspecification in Marketing and Consumer Research. Journal of Consumer Research 30 (September), 199-218.

Jerath, K., Zhang, J. Z., 2010. Store Within a Store. Journal of Marketing Research 47 (4), 748-763.

Johanson, J., Vahlne, J., 1977. The internationalization process of the firm - a model of knowledge development and increasing foreign commitments. Journal of International Business Studies 8 (1), 23-32.

Johanson, J., Vahlne, J., 1990. The mechanisms of internationalization. International Marketing Review 7 (4), 11-24.

Johanson, J., Vahlne, J-E., 2009. The Uppsala internationalization process model revisited: From liability of foreignness to liability of outsidership. Journal of International Business Studies 40 (9), 1411-1431.

Jonsson, A., Foss, N., 2011. International expansion through flexible replication: Learning from the internationalization experience of IKEA. Journal of International Business Studies 42, 1079-1102.

Kogut, B., Zander, U., 1993. Knowledge of the firm and the evolutionary theory of the multinational corporation. Journal of International Business Studies 24 (4), 625-645.

Krafft, M., Albers, S., Lal, R. 2004. Relative explanatory power of agency theory and transaction cost analysis in German sales forces. International Journal of Research in Marketing 21 (3), 265-283.

Laanti, R., Gabrielsson, M., Gabrielsson, P., 2007. The globalization strategies of B to B born global firms in the wireless technology industry. Industrial Marketing Management 36 (8), 1104-1117.

Lafontaine, F., Leibsohn, D., 2005. Beyond Entry: Examining McDonalds' Expansion in International Markets, In: Stanworth, J., Brodie, S. (Eds), Proceedings of the $19^{\text {th }}$ International Society of Franchising Conference, University of Westminster, London.

Lu, Y., Karpova, E. E., Fiore, A.M., 2011. Factors influencing international fashion retailers' entry mode choice. Journal of Fashion Marketing and Management 15 (1), 58 - 75.

Malhotra, N. K., Ulgado, F. M., Agarwal, J., 2003. Internationalization and entry modes: A Multitheoretical Framework and Research Propositions. Journal of International Marketing 11 (4), 1-31.

Moore, C.M., 1998. L'internationalisation du prêt-à-porter: The case of Kookai and Morgan's entry into the UK fashion market. Journal of Fashion Marketing and Management 2 (2), 153-158.

Moore C. M., 2000. The internationalisation of Foreign Fashion Retailers into the UK - Identifying the motives, methods and operational challenges. $\mathrm{PhD}$ dissertation, University of Stirling, Scotland.

Moore, C., Fernie, J., 2000. Americans in London: the internationalisation of fashion designer retailing. Journal of Fashion Marketing and Management 4 (3), 263-270.

Morschett D., Swoboda B., Schramm-Klein H., 2006. Competitive strategies in retailing-an investigation of the applicability of Porter's framework for food retailers, Journal of Retailing and Consumer Services 13 (4), 275-287.

Morschett, D., Schramm-Klein, H., Swoboda, B., 2010. Decades of research on market entry modes: What do we really know about external antecedents of entry mode choice?. Journal of International Management 16 (1) 60-77.

Park Y., Sternquist, B., 2008. The global retailer's strategic proposition and choice of entry mode. International Journal of Retail \& Distribution Management 36 (4), 281-299.

Pederzoli, D., 2006. Conception and test of a comprehensive model of international strategy for retail companies. International Review of Retail, Distribution \& Consumer Research 16 (4), 415-431.

Perrigot, R., López-Fernández, B., Eroglu, S. (2013). Intangible Resources and Plural Form as Drivers of Franchise Internationalization: Examination within a Two-Country Perspective. Journal of Small Business Management 51(4), 557-577.

Petersen, B., Welch, L.S., 2000. International retailing operations: downstream entry and expansion via franchising. International Business Review 9 (4), 479-496.

Petersen, B., Welch, L.S., 2002. Foreign Operation Mode Combinations and Internationalization. Journal of Business Research 55 (2), 157-162. 
Picot-Coupey, K., 2006. Determinants of International Retail Operation Mode Choice: Towards a Conceptual Framework Based on Evidence from French Specialised Retail Chains. International Review of Retail, Distribution and Consumer Research 16 (2), 215-237.

Picot-Coupey, K. 2009. Determinants of a Retailer's Choice of International Expansion Mode: Conceputal Model and Empirical Validation. Recherche et Applications en Marketing 24 (4), 23-54.

Quinn, B., 1998. Towards a framework for the study of franchising as an operating mode for international retail companies. The International Review of Retail, Distribution and Consumer Research 8 (4), 445-467.

Quinn, B., Alexander, N., 2002. International retail franchising: a conceptual framework. International Journal of Retail and Distribution Management 30 (5), 264-276.

Quinn, B., Doherty, A.M., 2000. Power and control in international retail franchising: evidence from theory and practice. International Marketing Review 17 (4/5), 354-372.

Ramon-Rodriguez, A., 2002. Determining factors in entry choice for international expansion - the case of the Spanish Hotel Industry. Tourism Management 23 (6), 597-607.

Ringle, C. M., Wende, S., Will, A., 2009. SmartPLS 2.0, Hamburg.

Root, F., 1994. Entry Strategies for International Markets. 2nd edition Lexington Books, Lexington MA.

Rossiter, J.R., 2002. The C-OAR-SE procedure for scale development in marketing. International Journal of Research in Marketing 19 (4), 305-335.

Salmon, W. J., Tordjman, A., 1989. The internationalisation of retailing. International Journal of Retailing 4 (2), 3-16.

Sharma, D., Blomstermo, A., 2003. The internationalization process of Born Globals: a network view. International Business Review 12 (6), 739-753.

Sparks, L., 1995. Reciprocal retail internationalization: the Southland corporation, Ito-Yokado and 7-eleven convenience stores. Services Industries Journal 15 (4), 57-96.

Sternquist, B., 1997. International expansion of US retailers. International Journal of Retail and Distribution Management 25 (8), 262-268.

Swoboda, B., Zentes, J., Elsner, S., 2009. Internationalisation of Retail Firms: State of the Art after 20 Years of Research. Marketing: Journal of Research and Management 5 (2), 105-126.

Treadgold, A., Davies, R.L., 1988. The internationalization of retailing, Longman, Harlow.

Vida, I., 2000. An empirical inquiry into international expansion of US retailers. International Marketing Review $17(4 / 5), 454-475$.

Vida, I., Fairhurst, A., 1998. International Expansion of retail firms: a theoretical approach for future investigations. Journal of Retailing and Consumer Services 5 (3), 143-151.

Vodlan, M., Vida, I., 2008. Multinationals in Central and Eastern Europe: a case study of international expansion by a Slovenian retailer. European Retail Research 22 (1), 137-157.

Watson, A., Stanworth, J., Healeas, S., Purdy, D., Stanworth, C., 2005. Retail franchising: an intellectual capital perspective. Journal of Retailing and Consumer Services 12 (1), 25-34.

Waldman, C., 1978. Strategies of International Mass Retailers. Praeger Publishers, New York.

Welch, D.E., Welch, L.S., 1996. The internationalization Process and Networks: A Strategic Management Perspective. Journal of International Marketing 4 (3), 11-28.

Welch, L.S., Benito, G., Petersen, B., 2007. Foreign Operation Methods - Theory, Analysis, Strategy. Edward Elgar, Cheltenham.

Wind, Y., Perlmutter, H.V., 1977. On the Identification of Frontier Issues in International Marketing. Columbia Journal of World Business 12 (4), 131-139.

Wrigley, N., Coe, N.M., Currah, A.D., 2005. Globalizing retail: conceptualizing the distribution-based TNC. Progress in Human Geography 29, (4), 437-457.

Wrona, T., Trapczynski, P., 2012. Re-explaining international entry modes - Interaction and moderating effects on entry modes of pharmaceutical companies into transition economies. European Management Journal 30, 295-315 
Figure 1- Theoretical framework for retailers' foreign expansion mode choice

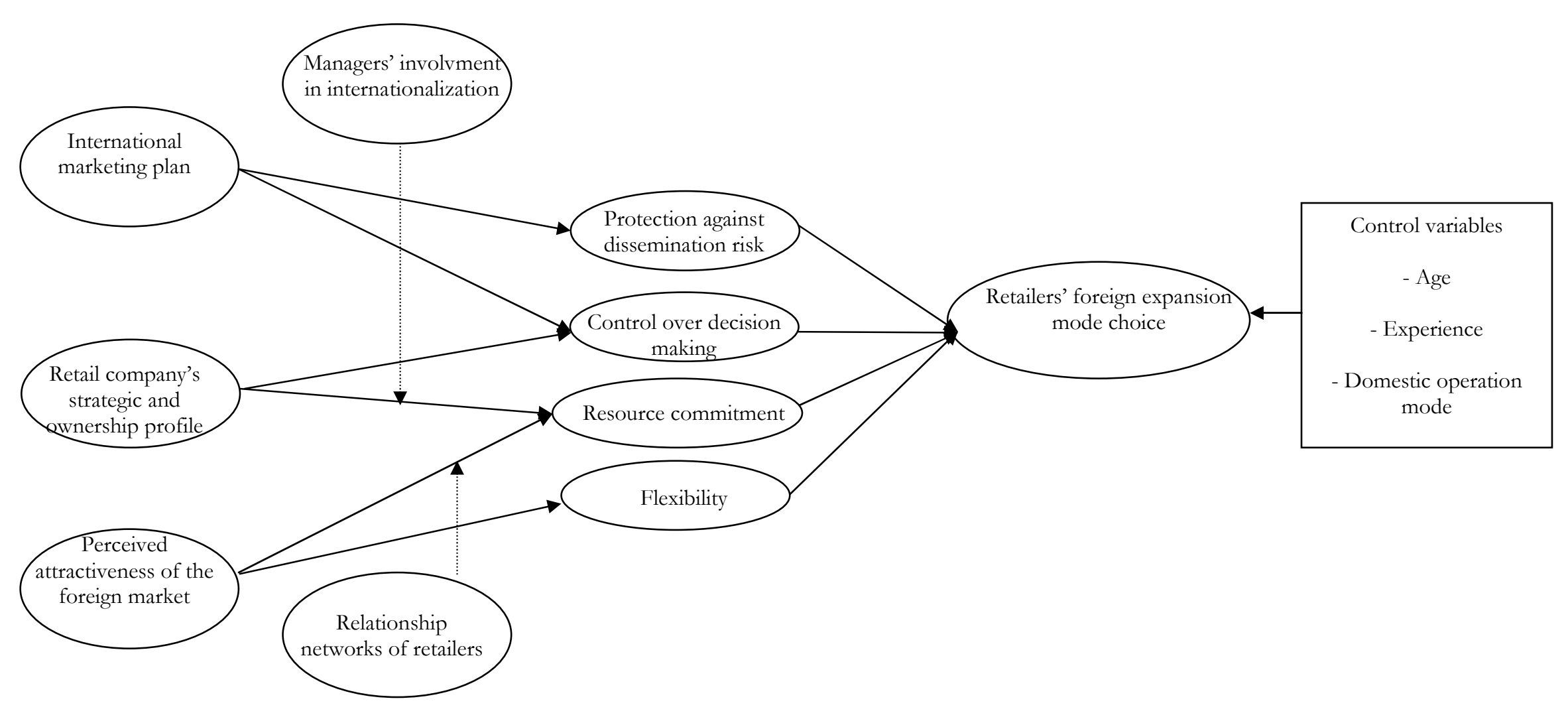


Figure 2 - Determinants of retail store networks' expansion mode choice: structural model results

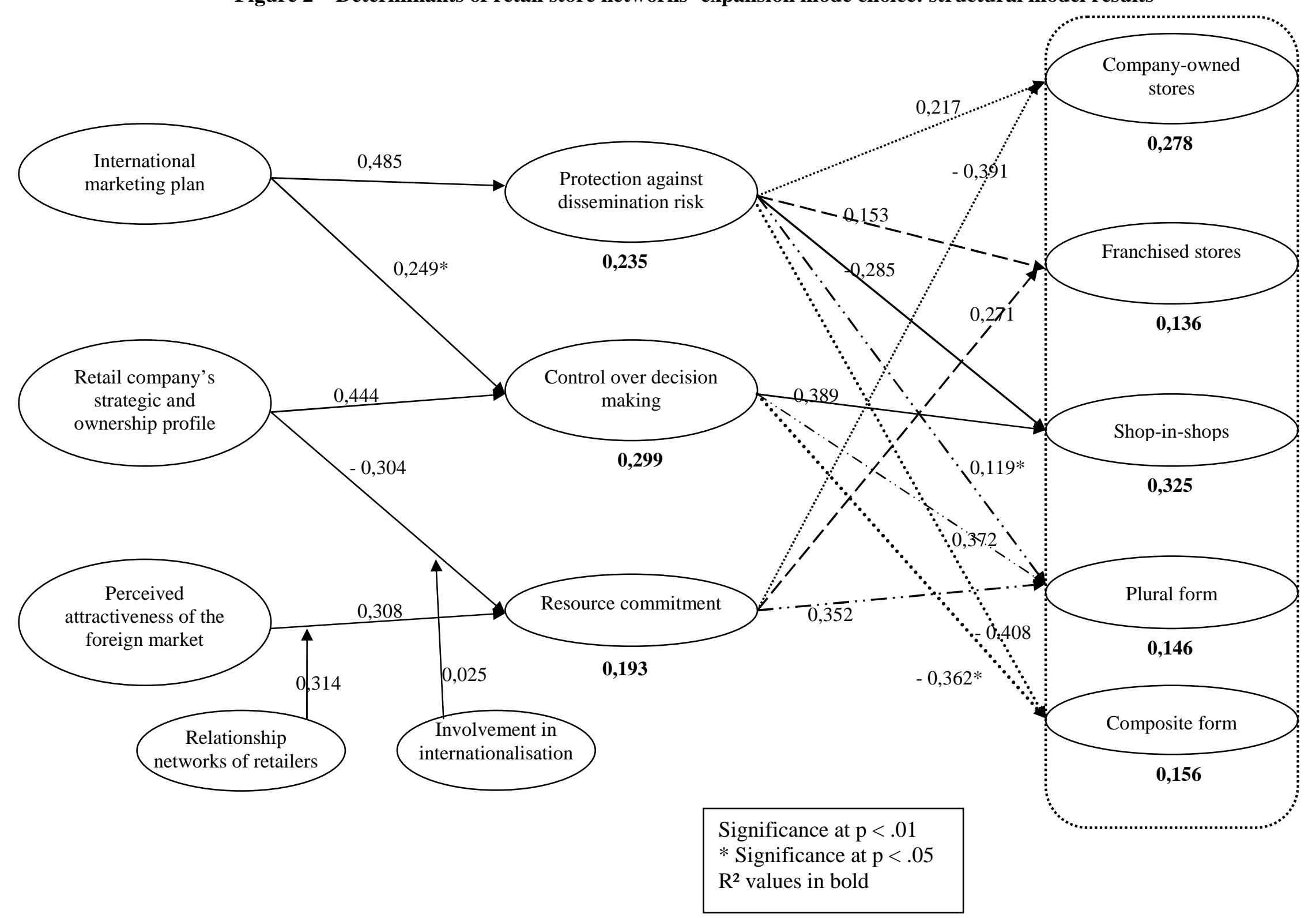


Figure 3 - Multitheoretical framework of retail expansion mode choice in foreign markets

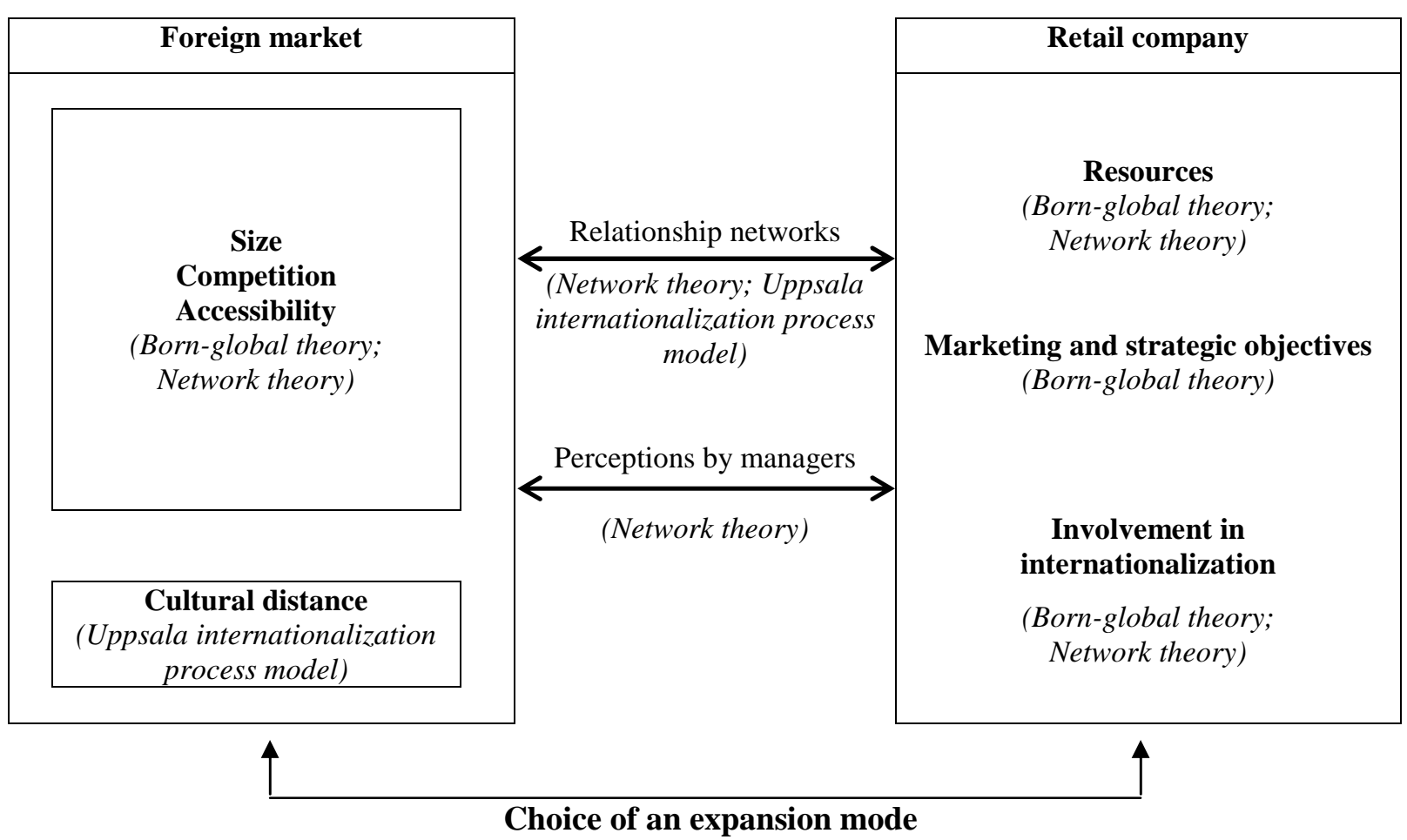


Table 1- Antecedents for FOM choice in internationalization theories

\begin{tabular}{|c|c|c|}
\hline & Internal antecedents & External antecedents \\
\hline Economic-strategic perspective & $\begin{array}{l}\text { - Product characteristics } \\
\text { - Ownership advantages (brand, } \\
\text { production technique, } \\
\text { entrepreneurial skills) } \\
\text { - International strategy } \\
\text { - Internalization advantages (tacit } \\
\text { knowledge, organization of core } \\
\text { competencies) }\end{array}$ & $\begin{array}{l}\text { - Location advantages (market } \\
\text { attractiveness) } \\
\text { - Industry characteristics } \\
\text { - Opportunism }\end{array}$ \\
\hline Behavioural perspective & $\begin{array}{l}\text { - Experiential knowledge } \\
\text { - Learning } \\
\text { - Resource endowment (financial, } \\
\text { human, technical resources) } \\
\text { - Entrepreneurial orientation } \\
\text { - Entrepreneurs' international } \\
\text { networks }\end{array}$ & $\begin{array}{l}\text { - Psychic distance } \\
\text { - Geographical distance } \\
\text { - Cultural differences } \\
\text { - Inter-organisational relationship } \\
\text { networks }\end{array}$ \\
\hline
\end{tabular}


Table 2- Categorization of retail FOMs along four characteristics

\begin{tabular}{|l|c|c|c|c|}
\hline & $\begin{array}{c}\text { Degree of } \\
\text { protection against } \\
\text { dissemination risk } \\
\text { of specific assets }\end{array}$ & $\begin{array}{c}\text { Degree of control } \\
\text { over decisions }\end{array}$ & $\begin{array}{c}\text { Amount of } \\
\text { resource } \\
\text { commitment }\end{array}$ & $\begin{array}{c}\text { Degree of } \\
\text { flexibility }\end{array}$ \\
\hline $\begin{array}{l}\text { Network operating } \\
\text { company-owned stores }\end{array}$ & Very high & Very high & Very high & Very low \\
\hline $\begin{array}{l}\text { Network operating } \\
\text { franchised stores }\end{array}$ & $\begin{array}{c}\text { Intermediate to } \\
\text { low } \\
\text { in-shops }\end{array}$ & $\begin{array}{c}\text { Intermediate to } \\
\text { low }\end{array}$ & Low & Intermediate to \\
high
\end{tabular}


Table 3 - Characteristics of the sample

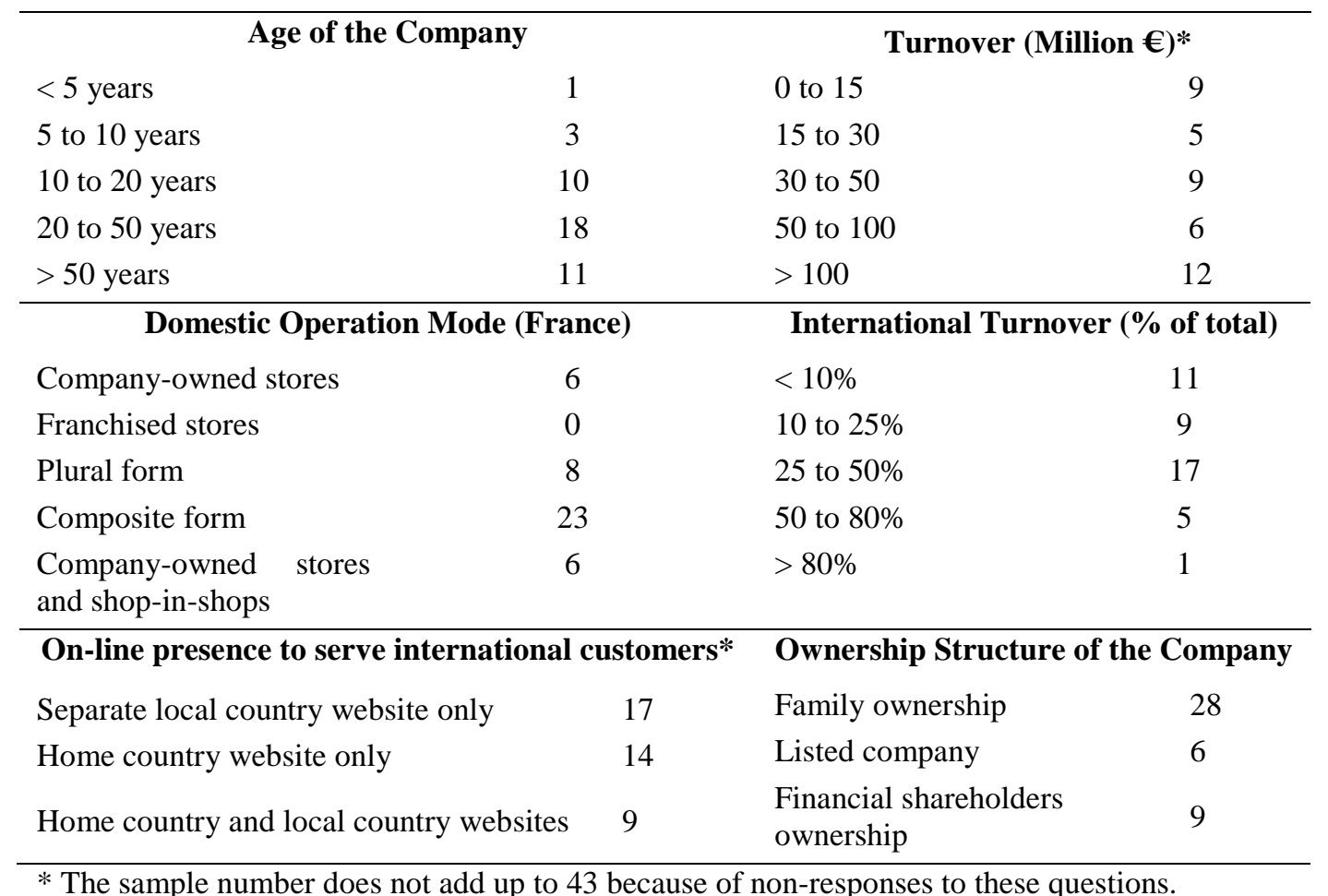

* The sample number does not add up to 43 because of non-responses to these questions. 
Table 4 - Scales and Indices Properties

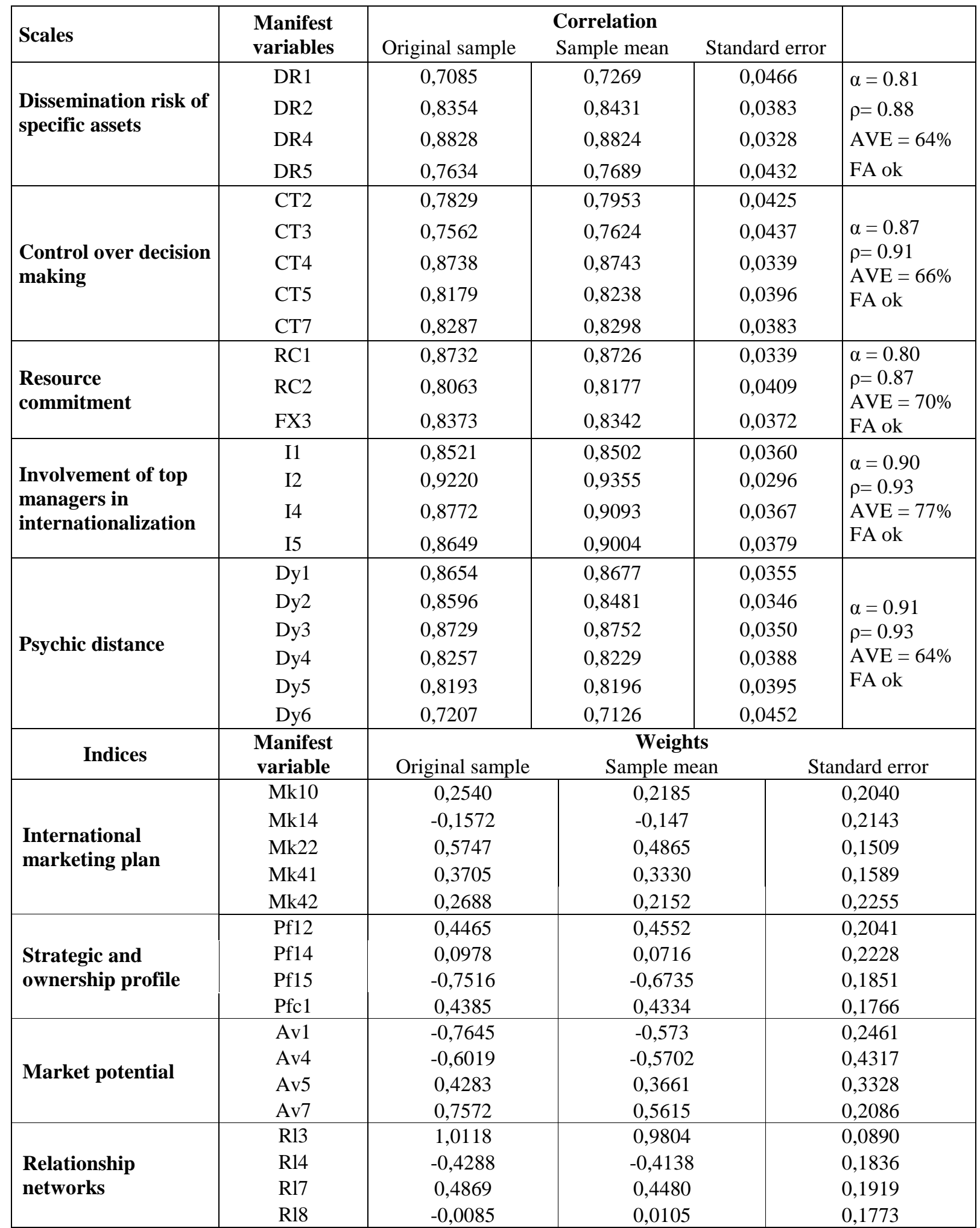

$\alpha=$ Cronbach alpha $-\rho=$ Dillon-Goldstein Rho - AVE $=$ Average Variance Extracted - FA $=$ Factor Analysis 
Table 5 - Cross-tabulation entry mode by expansion mode

\begin{tabular}{|c|c|c|c|c|c|c|c|c|}
\hline & & & & ansion $\mathrm{m}$ & & & & \\
\hline & & $\begin{array}{l}\text { Company } \\
\text { owned- } \\
\text { stores }\end{array}$ & $\begin{array}{c}\text { Franchise } \\
\text { stores }\end{array}$ & $\begin{array}{l}\text { Shops- } \\
\text { in-shops }\end{array}$ & $\begin{array}{l}\text { Plural } \\
\text { form }\end{array}$ & $\begin{array}{l}\text { Composite } \\
\text { form }\end{array}$ & Total & $\%$ \\
\hline & $\begin{array}{l}\text { Company-owned } \\
\text { stores }\end{array}$ & 11 & 1 & 0 & 1 & 1 & 14 & 32.6 \\
\hline & Franchise stores & 0 & 7 & 0 & 0 & 0 & 7 & 16.3 \\
\hline $\mathbf{\Xi}$ & Shops-in-shops & 5 & 3 & 7 & 1 & 1 & 17 & 39.5 \\
\hline & Composite form & 0 & 0 & 0 & 1 & 0 & 1 & 2.3 \\
\hline & $\begin{array}{l}\text { Other : franchise } \\
\text { stores and shops- } \\
\text { in-shops }\end{array}$ & 1 & 1 & 0 & 1 & 1 & 4 & 9.3 \\
\hline & Total & 17 & 12 & 7 & 4 & 3 & 43 & 100 \\
\hline & $\%$ & 39.5 & 27.9 & 16.3 & 9.3 & 7.0 & 100 & \\
\hline
\end{tabular}

Cramer $V=0,536 ; p=0,000-$ Contingency coefficient $=0,731 ; p=0,000$ 